OPEN ACCESS

Edited by:

Irida Kastrati,

Loyola University Chicago,

United States

Reviewed by:

Gamal Eldein Fathy Abd-Ellatef Abd-

Elrahman,

National Research Centre, Egypt

Yaswanth Kuthati,

Cathay General Hospital, Taiwan

${ }^{*}$ Correspondence:

Haibo Xu

haibo.xu@cdutcm.edu.cn

Specialty section:

This article was submitted to Pharmacology of Anti-Cancer Drugs, a section of the journal

Frontiers in Pharmacology

Received: 24 March 2021 Accepted: 09 June 2021

Published: 01 July 2021

Citation:

Sun $Q$, He $M$, Zhang $M$, Zeng $S$, Chen L, Zhao H, Yang H, Liu M, Ren $S$ and Xu H (2021) Traditional Chinese

Medicine and Colorectal Cancer:

Implications for Drug Discovery.

Front. Pharmacol. 12:685002.

doi: 10.3389/fphar.2021.685002

\section{Traditional Chinese Medicine and Colorectal Cancer: Implications for Drug Discovery}

\author{
Qiang Sun, Man He, Meng Zhang, Sha Zeng, Li Chen, Hui Zhao, Han Yang, Maolun Liu, \\ Shan Ren and Haibo $\mathrm{Xu}$ *
}

State Key Laboratory of Southwestern Chinese Medicine Resources, Department of Pharmacology, School of Pharmacy, Chengdu University of Traditional Chinese Medicine, Chengdu, China

As an important part of complementary and alternative medicine, traditional Chinese medicine (TCM) has been applied to treat a host of diseases for centuries. Over the years, with the incidence rate of human colorectal cancer (CRC) increasing continuously and the advantage of TCM gradually becoming more prominent, the importance of TCM in both domestic and international fields is also growing with each passing day. However, the unknowability of active ingredients, effective substances, and the underlying mechanisms of TCM against this malignant tumor greatly restricts the translation degree of clinical products and the pace of precision medicine. In this review, based on the characteristics of TCM and the oral administration of most ingredients, we herein provide beneficial information for the clinical utilization of TCM in the prevention and treatment of CRC and retrospect the current preclinical studies on the related active ingredients, as well as put forward the research mode for the discovery of active ingredients and effective substances in TCM, to provide novel insights into the research and development of innovative agents from this conventional medicine for CRC treatment and assist the realization of precision medicine.

Keywords: traditional Chinese medicine, colorectal cancer, drug discovery, bioactive ingredient, effective substance

\section{INTRODUCTION}

Colorectal cancer (CRC) is among the most common types of malignant tumors diagnosed globally worldwide and the second only to the death of lung cancer (Chen et al., 2020; La Vecchia and Sebastian, 2020), which accounts for approximately $10 \%$ of all annually diagnosed cancers and nearly 881,000 cancer-related deaths in 2018 (Bray et al., 2018). Unfortunately, the situation is becoming more severe. According to the latest research, there were 940,000 deaths attributed to CRC worldwide in 2020, with the deaths still increasing (Sung et al., 2021). Besides, it is the second most common tumor diagnosed in women and the third in men. It is worth mentioning that the incidence and mortality of women are approximately $25 \%$ lower than those in men (Dekker et al., 2019). Since the early symptoms are not extremely obvious, most patients are in the late stage after diagnosis. This cancer not only causes damage to the digestive system but also injures the lymph, liver, lung, bone, and so on, if the tumor metastases. Therefore, searching for an effective treatment schedule has become a research hotspot of scholars nationally and internationally.

The causes of CRC are relatively complicated and are mostly related to genetic, lifestyle, obesity, and environmental factors (Botteri et al., 2008; Kyrgiou et al., 2017; Siegel et al., 2020). According to 
incomplete statistics, surgical treatment is often used in the treatment of patients with nonmetastatic CRC, and most patients will have the disposition to resect part of the rectum or colon. In clinical practice, the recurrence and metastasis of advanced CRC are often treated with reoperation, chemotherapy, radiotherapy, targeted therapy, or other comprehensive treatments. Although great advances had been made in the diagnosis and treatment of $\mathrm{CRC}$, the prognosis for patients remains unsatisfactory (Salaga et al., 2014). In terms of agent intervention, 5-fluorouracil (5-FU) is currently a significant part of palliative and adjuvant systemic chemotherapy for CRC. Over the past decades, a variety of regulatory strategies such as the implementation of 5-FU-based combination regimens and 5-FU pro-drugs have been developed and tested to enhance the antineoplastic activity and to reduce clinical resistance. However, the response rate of patients to these treatments remains unfavorable, and the efficacy of 5-FU-based therapy is frequently compromised by the development of chemotherapy resistance (Marjaneh et al., 2018a; Vodenkova et al., 2020). In addition, irinotecan hydrochloride is a widely used broadspectrum cytotoxic agent for patients with advanced CRC. Unfortunately, in recent years, clinical practice has corroborated that there are fatal diarrhea dehydration, gastrointestinal damage, abdominal spasmodic pain, fever, and other adverse reactions (Chamseddine et al., 2019; Cheng et al., 2019; Hattori et al., 2019). Thus, more efficacious treatment strategies and approaches for medical intervention, especially the agent with high efficacy and few side effects, are an unmet medical need.

Traditional Chinese medicine (TCM), a predominant source of natural medicines and herbal products, are essential sources for exploiting anti-CRC agents (Kong et al., 2020). At present, although there is no convincing evidence in large-scale randomized controlled trials (RCTs) to support the therapeutic effect of TCM, a recent survey indicates that $20-30 \%$ of patients in Indonesia tend to use TCM to treat various diseases (Pengpid and Peltzer, 2018). Recent studies have found that TCM can be used as an effective auxiliary method to reduce the incidence rate of CRC (Ye et al., 2015; Wang et al., 2020). The effective components in Chinese herbs can destroy the living environment of cancer cells, promote apoptosis, enhance the individual's immunity, and eliminate the pathogens through the autoimmune system, so as to achieve the anticancer effect (Yan et al., 2017b; Zhang et al., 2020d; Qiao et al., 2020). Besides, TCM can be combined with other chemotherapy agents to reduce the adverse reactions caused by chemotherapy and significantly improve the quality of life of patients. Consequently, prior to the development of conclusive evidence-based available pharmacological therapies, the clinical utilization of TCM proves to be a nonignorable strategy for treating various diseases including CRC. The expanding knowledge of TCM in benefiting the treatment of CRC, against the extremely long period of modern drug discovery, has impelled researchers to excavate potential efficacious and secure therapies by the application of TCM, which is considered as "a natural combinatorial chemical gift library" drawing advantage from ancient practical experiences. Following the abovementioned thoughts, in this review, we first gave a brief introduction about the TCM products that have been approved for clinical research. Then, we summarized the scientific literature on the prevention and treatment of CRC with TCM and its bioactive compounds and reviewed the main molecular mechanisms involved in these processes. Finally, based on the characteristics of TCM, we put forward a slice of thoughts and prospects in future research, including reverse pharmacology guiding preclinical research, high-throughput screening of anti-CRC active ingredients, nanotargeted enrichment strategy, and gut-microbiota-mediated effect. This review will update the understanding of the effective material basis of anti-CRC with TCM and guide the discovery of novel agents from TCM.

\section{ANTITUMOR STATUS OF TRADITIONAL CHINESE MEDICINE AND ITS CLINICAL TRIALS ON COLORECTAL CANCER}

\section{Antitumor Status of Traditional Chinese Medicine}

As a long-standing science and culture, TCM has a centuries-old history of clinical use in the treatment of considerable maladies for thousands of years, and it has made contributions to the prosperity and civilization of the Chinese nation and the surrounding countries. Unlike chemical or biological products, TCM is usually applied as a prescription to achieve the treatment goal of related diseases. Consequently, in clinical practice, TCM formulas are prescribed by doctors under the guidance of ancient empirical philosophies such as Yin-Yang, monarch (Jun), minister (Chen), assistant ( $\mathrm{Zuo}$ ), and guide (Shi) (Dong et al., 2018). In recent years, with the acceleration of modernization and internationalization of TCM, the application of TCM in cancer treatment has become increasingly prominent. For instance, several reviews have described the wide application of TCM therapy on cancer treatment (Wang et al., 2018; Xiang et al., 2019; Liu et al., 2020c). Different from the idea of Western medicine, TCM emphasizes more on "holistic concept" and "survival with tumor," whose treatment goal is not only to kill cancer cells and reduce the size of the tumor but also to improve the quality of life and prolong the survival span of patients (Han et al., 2016). In addition to underlining the holistic health balance, TCM itself at least provides precious sources of anticancer agents, lead compounds, or adjuvant complements for novel drug discovery. TCM is rich in a battery of effective components, which carries the coordinated regulation of multitarget and multieffect. In the field of drug discovery, successful discovering of exhilarating compounds derived from TCM such as camptothecin, paclitaxel, and curcumin has brought much confidence for scientists to excavate natural antitumor agents (Hesari et al., 2019; Qu et al., 2019; Narayan et al., 2020).

\section{Clinical Trials of Traditional Chinese Medicine on Colorectal Cancer}

The ultimate goal of theoretical research is to successfully apply secure and effective agents to clinical practice. In this era of 
TABLE 1 | Clinical trials for TCM in treating CRC registered at ClinicalTrials.gov.

\section{Study title}

Strengthening the spleen and reducing phlegm Method in improving radical resection rate of colorectal cancer

Huaier granule as adjuvant therapy for colorectal cancer after radical surgery

Simo decoction and acupuncture on $\mathrm{POI}$ in colorectal cancer

Adjuvant chemotherapy combined with Huaier granule for treating high-risk stage II

and stage III colorectal cancer

Fuzheng Yiliu-1010

Study of TCM syndrome of hepatocellular carcinoma and colorectal cancer based on system science

Pomegranate extract supplementation in colorectal cancer patients

Effect of annona muricata leaves on colorectal cancer patients and colorectal cancer

cells

The efficacy of silymarin as adjuvant therapy on colorectal cancer patients undergoing

FOLFIRI treatment

Does dietary nitrate supplementation improve aerobic performance

Preventive strategies in colorectal carcinogenesis production and meat processing

Gemcitabine combined with mistletoe in treating patients with advanced solid tumors

Genistein in the treatment of metastatic colorectal cancer

Efficacy of ginseng for patients on regorafenib

Safety and effectiveness study of preoperative artesunate in stage II/III colorecta cancer (NeoART-V)

Avastin/FOLFIRI in combination with curcumin in colorectal cancer patients with unresectable metastasis

A pilot study of PPX in women with metastatic colorectal cancer

A safety and effectiveness study of preoperative artesunate in stage II/III colorectal cancer

Study of andrographolides with or without capecitabine to treat colorectal cancer

Effect of curcumin on dose-limiting toxicity and pharmacokinetics of irinotecan in patients with solid tumors

AZD2171 + chemotherapy in advanced NSCLC, colorectal cancer, or other cancers suitable for treatment with capecitabine (non-small-cell lung cancer patients closed to enrollment as 8/9/07)

Panitumumab skin toxicity prevention trial

Sulindac and plant compounds in preventing colon cancer

Curcumin for the prevention of colon cancer

Combining curcumin with FOLFOX chemotherapy in patients with inoperable

colorectal cancer

Resveratrol in treating patients with colorectal cancer that can be removed by surgery

Cancer-associated thrombosis and isoquercetin (CATIQ)

Preventive effect of enoxaparin, pentoxifylline, and ursodeoxycholic acid to radiationinduced liver toxicity

Berberine chloride in preventing colorectal cancer in patients with ulcerative colitis in remission

Paclitaxel and bortezomib in treating patients with metastatic or unresectable malignant solid tumors

Curcumin in combination with 5FU for colon cancer

Study investigating the ability of plant exosomes to deliver curcumin to normal and

colon cancer tissue

Resveratrol for patients with colon cancer

Phase III trial of gemcitabine, curcumin, and celebrex in patients with metastatic colon cancer

Radiation therapy and capecitabine with or without curcumin before surgery in treating patients with rectal cancer

Efficacy and safety evaluation of traditional Chinese medicine in the treatment of

advanced colorectal cancer

Dietary bioflavonoid supplementation for the prevention of neoplasia recurrence

\section{Drugs involved}

Jianpi Huatan dispensing granule

Huaier granule

Simo decoction

Huaier granule

Fuzheng Yiliu formulation

Bushen-Jianpi dedoction/

Cinobufotalin injection

Pomegranate extract

Annona muricata extract

Silymarin

Beetroot juice

Pomegranate extract

Mistletoe extract

Genistein

Ginseng

Artesunate

Curcumin

Paclitaxel Poliglumex

Artesunate

Andrographolides

Curcumin

Paclitaxel

Lycopene

Curcumin/rutin/quercetin

Curcumin

Curcumin

Resveratrol

Isoquercetin

Ursodeoxycholic acid

Berberine chloride

Paclitaxel

Curcumin

Curcumin

Resveratrol

Curcumin

Curcumin

Unknown

Flavonoids
Status

Not recruiting, N/A

Unknown, N/A

Completed, phase 3

Unknown, N/A

Recruiting, phase 2

Recruiting, phase 1

Completed, phase 1/2

Completed, phase 1

Completed, phase 4

Not recruiting, phase 4

Completed, N/A

Terminated, phase 1

Completed, phase 1/2

Terminated (funder

terminated)

Recruiting, phase 2

Completed, phase 2

Completed, phase 1

Recruiting, phase 2

Terminated (low accrual rate)

Completed, phase 1

Completed, phase 1

NCT00107250

Recruiting, phase 2

Completed, N/A

Completed, phase 1

Completed, phase 1/2

Completed, phase 1

Not recruiting

Completed, phase 2

Not recruiting

Completed, phase 1

Not recruiting

Not recruiting

Completed, phase 1

Unknown

Not recruiting

Not recruiting, N/A

Suspended, phase 2
Identifier

NCT03716063

NCT02796820

NCT02813278

NCT02785146

NCT04459754

NCT03189992

NCT01916239

NCT02439580

NCT03130634

NCT02319356

NCT02473302

NCT00049608

NCT01985763

NCT02581059

NCT03093129

NCT02439385

NCT00598247

NCT02633098

NCT01993472

NCT01859858

NCT03167268

NCT00003365

NCT00027495

NCT01490996

NCT00433576

NCT02195232

NCT01149304

NCT02365480

NCT00667641

NCT02724202

NCT01294072

NCT00256334

NCT00745134

NCT02923622

NCT00609310
NCT00295035 "precision medicine" and "evidence-based medicine," it is extremely paramount to carry out large-scale randomized controlled trials of TCM to conclusively confirm whether it is effective in the treatment of related diseases. In order to promote the modernization and internationalization of TCM, the Chinese government launched a grand plan to expand the basic and clinical research of TCM in 2007, which has achieved great results (Qiu, 2007). By setting "colorectal cancer" or "CRC" as 
the keywords, we searched the website of ClinicalTrails.gov (https://clinicaltrials.gov/) and found that there were 5,833 kinds of clinical studies that have been conducted with CRC (on January 28, 2021), of which 38 were related to TCM (in addition to some dietary supplements from botany), including Chinese medicine formula (CMF), Chinese herbal extracts, and Chinese herbal single compounds (Table 1). These clinical projects have brought powerful confidence for the anti-CRC of the active ingredients in TCM, which will promote and accelerate the clinical transformation of TCM products against CRC.

\section{Traditional Chinese Medicine Preclinical Trials on Colorectal Cancer}

At present, due to the overall regulatory effect of TCM on human body and low toxicity and side effects, the research on diseases including CRC is increasing all over the world (Fan et al., 2020). At the same time, great progress has been made in its pharmacological research and clinical application. Also, the high $\mathrm{R} \& \mathrm{D}$ cost and long $\mathrm{R} \& \mathrm{D}$ time of chemosynthetic agents also prompt pharmaceutical scientists to enhance their efforts in mining novel and effective antitumor agents from TCM ingredients. In general, rapid advancement in the discovery of active components of TCM has provided an array of opportunities for developing novel anti-CRC therapeutic strategies.

\section{Anti-Colorectal-Cancer Effect of Chinese Medicine Formula}

As an ancient science and culture, Chinese medicine formula (CMF) has a centuries-old history in clinical treatment of considerable ailments for thousands of years, and TCM has made many contributions to the prosperity and civilization of China and other neighboring countries (Luan et al., 2020; You et al., 2020). The rational compatibility of TCM should follow the principle of "monarch (Jun), minister (Chen), assistant (Zuo), and guide (Shi)" in the theory of TCM, rather than the simple combination of various herbal medicine or compounds. In this theory, "monarch (Jun), minister (Chen), assistant (Zuo), and guide (Shi)" represent the corresponding agents in the prescription, respectively. "Monarch drug" plays a major therapeutic role and "minister drug" can enhance the curative effect of "monarch drug," while "assistant drug" can cooperate with "monarch drug" and "minister drug" to undermine possible side effects. "Guide drug" can lead other components to the pathogenic part of the ingredients. The CMF is rich in an ocean of components and has complex pharmacological effects, which can exert an antitumor effect through a variety of approaches (Liu et al., 2015; Wan et al., 2018; Lee et al., 2020). It has been verified that a variety of CMF can significantly improve the quality of life and survival rate of CRC patients through the overall regulatory effect (Chu et al., 2015; Lin et al., 2017). For example, Shaoyao decoction (SYD), a traditional CMF formulated by the master in Jin-Yuan Dynasty Liu Wan-Su, consisting of Shaoyao, Binglang, Dahuang, Huangqin, Huanglian, Danggui, Guangui, Gancao, and Muxiang, has been proved to significantly elevate the survival rate of the mice and reduced the incidence of colonic neoplasms (Lin et al., 2014). Additionally, it is reported that herbal formula Huang Qin Ge Gen Tang can potentiate the antitumor activity of 5-FU by regulating the E2F1/TS pathway (Liu et al., 2018).

When it comes to CMF, we have to call to mind the Chinese medicine pair in TCM. The Chinese medicine pair is a part between compound CMF and single Chinese medicine. It is a combination of two commonly used herbs in clinical practice of TCM, and it is also a basic form of compatibility and application in TCM. Generally speaking, the Chinese medicine pair possesses a better curative effect or lower toxicity than single Chinese medicine, which is the accumulation of ancient empiricism philosophy (Zhou et al., 2017; Xu et al., 2020). With the method of network pharmacology, researchers found that the herb pair "Huang Lian-Gan Jiang" can regulate 500 biological processes and 70 molecular functions, affect 62 related signaling pathways, and then, exert the prevention and treatment of CRC (Gong et al., 2019). In a study on the herb pair Hedyotis diffusa and Sculellaria barbata against CRC, it was found that this compatibility of medicines inhibited the tumor growth both in vitro and in vivo, which might be related to apoptosis induction through the EGFR/PPAR gamma/PI3K/AKT pathway (Lu et al., 2020a). Another study showed that the combination pair Panax ginseng and Veratrum nigrum decreased cell proliferation via inducing cell cycle arrest and apoptosis of CT 26 and HT 29 cells, as well as suppressed metastatic abilities of the abovementioned two cells including epithelial-mesenchymal transition (EMT), migration, and invasion (Kee et al., 2018).

With the development of TCM pharmaceutics, some CMFs have been developed into Chinese patent medicine for the prevention and treatment of CRC. Chinese patent medicine is the novel CMF developed by the modern pharmaceutical technology under the TCM principle of syndrome differentiation and treatment, which can exert an anti-CRC effect by interfering with multiple processes. For instance, as the report goes, Da Huang Zhe Chong Pill halted the CRC liver metastasis by ameliorating exosomal CCL2 primed premetastatic niche (Chen et al., 2019). Pian Zi Huang, a prescription preparation, can suppress the proliferation and induce apoptosis of CRC stem cells by inhibiting the Notch1 signaling pathway (Wei et al., 2014; Qi et al., 2016). Additionally, it can effectively surmount MDR of 5-FU and block the EMT in human colorectal carcinoma cells by inhibiting the TGF-beta signaling pathway (Shen et al., 2014). More detailed information concerning anti-CRC of CMF is depicted in Table 2.

\section{Anti-Colorectal-Cancer Effect of Traditional Chinese Medicine Extract}

TCM extract is a kind of TCM product with a relatively clear pharmacodynamic material basis and strict quality standard, which is a novel product form in the international natural medicine market and can be widely used in natural health products (Shen et al., 2017; Bu et al., 2020). At present, a variety of preclinical works on the anti-CRC effect of TCM extracts (water extract, ethanolic extract, chloroform extract, 
TABLE 2 | CMFs for anti-CRC and corresponding mechanisms.

\begin{tabular}{|c|c|c|c|c|c|c|}
\hline CMF name & Composition & $\begin{array}{l}\text { Cell lines/ } \\
\text { model }\end{array}$ & Dose & Detail & Mechanism & Ref \\
\hline $\begin{array}{l}\text { Fu Fang Yi Liu } \\
\text { Yin formula }\end{array}$ & $\begin{array}{l}\text { Astragali Radix, Ganoderma lucidum, } \\
\text { semen armeniacae amarum, H. diffusa } \\
\text { Willd., Aconiti Lateralis Radix Praeparata, } \\
\text { Glycyrrhiza glabra Linn., Radix Panacis } \\
\text { Quinquefolii, and Platycodi Radix }\end{array}$ & $\begin{array}{l}\text { HCT } 116 \text { cells } \\
\text { SW } 480 \text { cells } \\
\text { BALB/c mice }\end{array}$ & $\begin{array}{l}3-15 \mathrm{mg} / \mathrm{ml} \\
3-15 \mathrm{mg} / \mathrm{ml} \\
2.4 \mathrm{mg} / \mathrm{g}\end{array}$ & $\begin{array}{l}\text { In vitro } \\
\text { In vitro } \\
\text { In vivo }\end{array}$ & $\begin{array}{l}\text { Inhibit cell proliferation and induce } \\
\text { apoptosis and block cell at } G_{0} / G_{1} \text { phase. } \\
\text { In vivo, inhibit tumor growth }\end{array}$ & $\begin{array}{l}\text { Dong } \\
\text { et al. } \\
(2020)\end{array}$ \\
\hline $\begin{array}{l}\text { Yi Fu Zi Bai } \\
\text { Jiang San }\end{array}$ & $\begin{array}{l}\text { Semen coicis, monkshood, and Herba } \\
\text { Patriniae }\end{array}$ & $\begin{array}{l}\text { HCT } 116 \text { cells } \\
\text { MC } 38 \text { cells } \\
\text { C57BL/6 J } \\
\text { mice }\end{array}$ & $\begin{array}{l}15.625-62.5 \mu \mathrm{g} / \mathrm{ml} \\
15.625-62.5 \mu \mathrm{g} / \mathrm{ml} \\
3.825-15.3 \mathrm{~g} / \mathrm{kg}\end{array}$ & $\begin{array}{l}\text { In vitro } \\
\text { In vitro } \\
\text { In vivo }\end{array}$ & $\begin{array}{l}\text { Block tumor initiation and progression, } \\
\text { increase immune function, regulate gut } \\
\text { flora, alter cell growth, and reduce } \\
\text { phosphorylation of } \beta \text {-catenin }\end{array}$ & $\begin{array}{l}\text { Sui et al. } \\
(2020)\end{array}$ \\
\hline $\begin{array}{l}\text { Astragalus } \\
\text { atractylodes } \\
\text { mixture }\end{array}$ & $\begin{array}{l}\text { Astragalus membranaceus, Atractylodes } \\
\text { macrocephala, Actinidia arguta, Curcuma } \\
\text { aromatica, Benincasa hispida, and Ficus } \\
\text { pumila. }\end{array}$ & $\begin{array}{l}\text { HCT } 116 \text { cells } \\
\text { LoVo cells }\end{array}$ & $\begin{array}{l}0.5-16 \mathrm{mg} / \mathrm{ml} \\
0.5-16 \mathrm{mg} / \mathrm{ml}\end{array}$ & $\begin{array}{l}\text { In vitro } \\
\text { In vitro }\end{array}$ & $\begin{array}{l}\text { Inhibit hypoxia-induced ROS generation, } \\
\text { migration and VM formation, as well as } \\
\text { HIF-1 alpha and MMP2 expression }\end{array}$ & $\begin{array}{l}\text { Zong et al. } \\
(2020)\end{array}$ \\
\hline $\begin{array}{l}\text { Xiang Sha Liu } \\
\text { Jun Zi decoction }\end{array}$ & $\begin{array}{l}\text { Radix Codonopsis, rhizoma Atractylodis } \\
\text { macrocephalae, radix glycyrrhizae, Poria, } \\
\text { Pericarpium citri reticulatae, Pinellia tuber, } \\
\text { Radix Aucklandiae, and Fructus Amomi }\end{array}$ & $\begin{array}{l}\text { Patients with } \\
\text { stage III or } \\
\text { IV CRC }\end{array}$ & Unknown & In vivo & Unknown & $\begin{array}{l}\text { Hong } \\
\text { et al. } \\
(2020)\end{array}$ \\
\hline Wu Mei Wan & $\begin{array}{l}\text { Fructus Mume, rhizoma coptidis, Herba } \\
\text { Asari Mandshurici, Ramulus Cinnamomi, } \\
\text { Radix Ginseng, Radix Aconiti Lateralis } \\
\text { Preparata, Pericarpium Zanthoxyli } \\
\text { Bungeani, Rhizoma Zingiberis, Cortex } \\
\text { Phellodendri Amurensis, and Radix } \\
\text { Angelicae Sinensis }\end{array}$ & $\begin{array}{l}\text { C57BL/6 J } \\
\text { mice }\end{array}$ & $5.8 \mathrm{~g} / \mathrm{kg}$ & In vivo & $\begin{array}{l}\text { Improve the survival rate and attenuate } \\
\text { symptoms, reduce proliferation of tumor } \\
\text { cells, decrease the expression of p65, IL- } \\
6 \text {, and p-STAT3, decrease } \\
\text { Bacteroidetes, and increase Firmicutes }\end{array}$ & $\begin{array}{l}\text { Jiang et al. } \\
(2020)\end{array}$ \\
\hline Zuo Jin Wan & $\begin{array}{l}\text { Coptis chinensis Franch. and Evodia } \\
\text { ruticarpa }\end{array}$ & $\begin{array}{l}\text { HCT } 116 \text { cells } \\
\text { HT } 29 \text { cells }\end{array}$ & $\begin{array}{l}100-300 \mu \mathrm{M} \\
100-300 \mu \mathrm{M}\end{array}$ & $\begin{array}{l}\text { In vitro } \\
\text { In vitro }\end{array}$ & $\begin{array}{l}\text { Induce apoptosis through the PI3K-Akt } \\
\text { signaling pathway }\end{array}$ & $\begin{array}{l}\text { Huang } \\
\text { et al. } \\
\text { (2020b) }\end{array}$ \\
\hline Zuo Jin Wan & $\begin{array}{l}\text { Coptis chinensis Franch. and Evodia } \\
\text { ruticarpa }\end{array}$ & SW 403 cell & $25-800 \mu \mathrm{g} / \mathrm{ml}$ & In vitro & $\begin{array}{l}\text { Increase } \mathrm{G}_{1} \text { arrest in cell cycle, induce } \\
\text { apoptosis, suppress cell migration and } \\
\text { invasion, and decrease the expression of } \\
5 \text {-HTR1D and } \beta \text {-catenin }\end{array}$ & $\begin{array}{l}\text { Pan et al. } \\
(2017)\end{array}$ \\
\hline $\begin{array}{l}\text { Compound } \\
\text { sophorae } \\
\text { decoction }\end{array}$ & $\begin{array}{l}\text { Sophora flavescens and Sanguisorba } \\
\text { officinalis, Indigo naturalis, Bletilla striata, } \\
\text { Panax notoginseng, and Glycyrrhiza } \\
\text { uralensis }\end{array}$ & $\begin{array}{l}\text { C57BL/6 J } \\
\text { mice }\end{array}$ & $0.1614 \mathrm{~g}$ & In vivo & $\begin{array}{l}\text { Execute UCRCC-inhibitory activity by } \\
\text { counteracting inflammatory responses } \\
\text { and rescuing detuning of apoptosis as } \\
\text { well as neutralizing overactive mitophagy }\end{array}$ & $\begin{array}{l}\text { Deng et al. } \\
\text { (2019) }\end{array}$ \\
\hline $\begin{array}{l}\text { Qing Jie Fu } \\
\text { Zheng granules }\end{array}$ & $\begin{array}{l}\text { Scutellaria barbata, malt, Hedyotis diffusa, } \\
\text { and Astragalus mongholicus }\end{array}$ & $\begin{array}{l}\text { HCT } 8 \text { cells } \\
\text { HCT } 116 \text { cells }\end{array}$ & $\begin{array}{l}0.5-2 \mathrm{mg} / \mathrm{ml} \\
0.5-2 \mathrm{mg} / \mathrm{ml}\end{array}$ & $\begin{array}{l}\text { In vitro } \\
\text { In vitro }\end{array}$ & $\begin{array}{l}\text { Inhibit proliferation and induce apoptosis } \\
\text { by suppressing the PI3K/AKT and ERK } \\
\text { pathways }\end{array}$ & $\begin{array}{l}\text { Yang et al. } \\
\text { (2019a) }\end{array}$ \\
\hline $\begin{array}{l}\text { Si Jun Zi } \\
\text { decoction }\end{array}$ & $\begin{array}{l}\text { Codonopsis pilosula, Poria cocos, } \\
\text { Atractylodes macrocephala, and radix } \\
\text { liquiritiae }\end{array}$ & Balb/c mice & $45 \mathrm{~g} / \mathrm{kg}$ & In vivo & $\begin{array}{l}\text { Increase survival rate and reduce liver } \\
\text { metastasis, elevate plasma GM-CSF } \\
\text { level, and increase the number of } \\
\text { macrophages but not neutrophils in the } \\
\text { spleen }\end{array}$ & $\begin{array}{l}\text { Zhou et al. } \\
\text { (2019a) }\end{array}$ \\
\hline Chang Wei Qing & $\begin{array}{l}\text { Astragalus membranaceus, Atractylodes } \\
\text { macrocephala, Codonopsis pilosula, } \\
\text { Akebia quinata, Polyporus umbellatus, } \\
\text { Coix seed, Vitis quinquangularis Rehder, } \\
\text { and Sargentodoxa cuneata }\end{array}$ & $\begin{array}{l}\text { C57BL/6 J } \\
\text { mice }\end{array}$ & $5,10 \mathrm{mg} / \mathrm{kg}$ & In vivo & $\begin{array}{l}\text { Restore colon length, decrease tumor } \\
\text { number and size, reduce colitis score, } \\
\text { suppress expansion of } F \text {. prausnitzii } \\
\text { population, and inhibit activity of beta- } \\
\text { glucuronidase and leakage of D-lactose } \\
\text { and endotoxin }\end{array}$ & $\begin{array}{l}\text { Wan et al. } \\
\text { (2019) }\end{array}$ \\
\hline $\begin{array}{l}\text { Su Yang } \\
\text { decoction }\end{array}$ & Broccoli and green cabbage & $\begin{array}{l}\text { HT } 29 \text { cells } \\
\text { LS 174-T cells } \\
\text { CRL-1790 } \\
\text { cells }\end{array}$ & $\begin{array}{l}10-200 \mu \mathrm{g} / \mathrm{ml} \\
10-200 \mu \mathrm{g} / \mathrm{ml} \\
10-200 \mu \mathrm{g} / \mathrm{ml}\end{array}$ & $\begin{array}{l}\text { In vitro } \\
\text { In vitro } \\
\text { In vitro }\end{array}$ & $\begin{array}{l}\text { Inhibit colon cancer cell proliferation and } \\
\text { induce } \mathrm{G}_{1} \text { phase arrest and induce the } \\
\text { cleavage of poly (ADP-ribose) } \\
\text { polymerase, tumor necrosis factor } \\
\text { superfamily member } 10, \mathrm{X} \text {-linked } \\
\text { inhibitor of apoptosis }\end{array}$ & $\begin{array}{l}\text { Ge et al. } \\
(2019)\end{array}$ \\
\hline $\begin{array}{l}\text { Jian Pi Jie Du } \\
\text { decoction }\end{array}$ & $\begin{array}{l}\text { Astragalus membranaceusceus, Panax } \\
\text { quinquefolius, Atractylodes macrocephala, } \\
\text { Poria cocos, Coix seed, Smilax china, } \\
\text { Hedyotis diffusa, Sculellaria barbata, Paris } \\
\text { polyphylla, Actinidia argut, and } \\
\text { gGlycyrrhiza uralensis Fisch. }\end{array}$ & $\begin{array}{l}\text { HCT116 cells } \\
\text { HT29 cells } \\
\text { LoVo cells } \\
\text { SW48 cells }\end{array}$ & $\begin{array}{l}0.3125-2.5 \mathrm{mg} / \mathrm{ml} \\
0.3125-2.5 \mathrm{mg} / \mathrm{ml} \\
0.3125-2.5 \mathrm{mg} / \\
0.3125-2.5 \mathrm{mg} / \mathrm{ml}\end{array}$ & $\begin{array}{l}\text { In vitro } \\
\text { In vitro } \\
\text { In vitro } \\
\text { In vitro }\end{array}$ & $\begin{array}{l}\text { Inhibit viability and proliferation, induce } \\
\text { apoptosis, suppress migration, invasion, } \\
\text { and angiogenesis by inhibiting the } \\
\text { mTOR/HIF-1 } \alpha \text { NEGF signaling pathway, } \\
\text { decrease the CD34 and VEGF, and } \\
\text { downregulate the mTOR/HIF-1 a/VEGF } \\
\text { pathway }\end{array}$ & $\begin{array}{l}\text { Peng et al. } \\
\text { (2018) }\end{array}$ \\
\hline Tian Xian liquid & & HT29 cells & $0.625-5 \%(v / v$ & In vitro & & \\
\hline
\end{tabular}


TABLE 2 | (Continued) CMFs for anti-CRC and corresponding mechanisms.

\begin{tabular}{|c|c|c|c|c|c|c|}
\hline CMF name & Composition & $\begin{array}{l}\text { Cell lines/ } \\
\text { model }\end{array}$ & Dose & Detail & Mechanism & Ref \\
\hline & $\begin{array}{l}\text { Radix Ginseng, Cordyceps, Radix } \\
\text { Astragali, Radix Glycyrrhizae, rhizoma, } \\
\text { margarita, Fructus lycii, Ganoderma } \\
\text { lucidum, Fructus ligustri lucidi, and Herba } \\
\text { Scutellariae barbatae }\end{array}$ & Nude mice & $200 \mu \mathrm{l}$ & In vivo & $\begin{array}{l}\text { Inhibit proliferation, upregulate the p21 } \\
\text { mRNA and protein, downregulate } \mathrm{G}_{1} \\
\text { phase cell cycle protein, cyclin D1 mRNA } \\
\text { and protein, and reverse multidrug } \\
\text { resistance }\end{array}$ & $\begin{array}{l}\text { Leigh } \\
\text { et al. } \\
(2017)\end{array}$ \\
\hline Yi Ai Fang & $\begin{array}{l}\text { Astragalus membranaceus, Atractylis } \\
\text { ovate, Actinidia arguta, Curcuma zedoaria, } \\
\text { and Benincasa hispida }\end{array}$ & $\begin{array}{l}\text { BABL/c mice } \\
\text { HCT } 116 \text { cells }\end{array}$ & $\begin{array}{l}8-32 \mathrm{mg} / \mathrm{kg} \\
25-200 \mu \mathrm{g} / \mathrm{ml}\end{array}$ & $\begin{array}{l}\text { In vivo } \\
\text { In vitro }\end{array}$ & $\begin{array}{l}\text { Restrain the formation of vasculogenic } \\
\text { mimicry through the HIF- } 1 \alpha / E M T \\
\text { pathway, inhibit growth of the } \\
\text { xenografted tumors, enhance } \\
\text { expression of E-cd and claudin- } 4 \text {, and } \\
\text { decrease the expression of HIF-1a } \\
\text { and VIM }\end{array}$ & $\begin{array}{l}\text { Hou et al. } \\
\text { (2016) }\end{array}$ \\
\hline $\begin{array}{l}\text { Huang Qin } \\
\text { decoction }\end{array}$ & $\begin{array}{l}\text { Scutellaria baicalensis Georgi., Paeonia } \\
\text { lactiflora Pall., Glycyrrhiza uralensis Fisch., } \\
\text { and Ziziphus jujuba Mill. }\end{array}$ & C57BL/6 mice & $9.1 \mathrm{~g} / \mathrm{kg}$ & In vivo & $\begin{array}{l}\text { Inhibit AOM/DSS-induced CRC and the } \\
\text { production of inflammatory cytokines } \\
\text { and increase antioxidant capacity both in } \\
\text { chronic DSS- and AOM/DSS-treated } \\
\text { mice }\end{array}$ & $\begin{array}{l}\text { Chen et al. } \\
\text { (2016) }\end{array}$ \\
\hline $\begin{array}{l}\text { Shen Ling Bai } \\
\text { Zhu San }\end{array}$ & $\begin{array}{l}\text { Radix et rRhizoma gGinseng, Poria, } \\
\text { Rhizoma Atractylodis Macrocephalae, } \\
\text { semen Lablab Album, Rhizoma } \\
\text { Dioscoreae, Radix et Rhizoma }\end{array}$ & $\begin{array}{l}\text { C57BL/6 J } \\
\text { mice } \\
\text { SW480 cells } \\
\text { HCT116 cells }\end{array}$ & $\begin{array}{l}3.64-14.56 \mathrm{~g} / \mathrm{kg} \\
6-16 \mathrm{mg} / \mathrm{ml} \\
6-16 \mathrm{mg} / \mathrm{ml}\end{array}$ & $\begin{array}{l}\text { In vivo } \\
\text { In vitro } \\
\text { In vitro }\end{array}$ & $\begin{array}{l}\text { Supress colitis-associated CRC through } \\
\text { the inhibition of EMT and myeloid- } \\
\text { derived suppressor infiltration }\end{array}$ & $\begin{array}{l}\text { Lin et al. } \\
(2015)\end{array}$ \\
\hline
\end{tabular}

Glycyrrhizae, Plumula nelumbinis, Fructus

Amomi, semen coicis, and Radix

Platycodonis

Jian Pi Hua Yu Atractylodes macrocephala Koidz.,

decoction

Euphorbia humifusa Willd., Salvia

miltiorrhiza Bunge., Paris polyphylla Sm., Curcuma phaeocaulis Val., Scutellaria barbata D. Don., and Artemisia capillaris Thunb.

Yi Qi Fu Sheng formula

Codonopsis pilosula, Atractylodes macrocephala, Poria cocos, Radix liquiritiae, Myristica fragrans, and Fructus Akebiae

Jian Pi Jie Du recipe Radix Astragal, Rhizoma Atractylodis macrocephala, wild grapevines, Fructus Akebia, Salvia chinensis Benth., and Evodia rutaecarpa

Huang Lian Jie Du decoction

Coptis chinensis Franch., Phellodendron amurense Rupr., Gardenia jasminoides J. Ellis, and Scutellaria baicalensis Georgi.
Athymic mice

50-200 mg/kg

HCT-116 cells

Athymic mice

LoVo cells

Nude mice

$12.5-400 \mu \mathrm{g} / \mathrm{ml}$ $250-1,000 \mathrm{mg} / \mathrm{kg}$

In vivo

$$
\text { In } \mathrm{v}
$$

\section{In} orthotopic $\mathrm{CRC}$, prolonging the survival time

In vivo Promote renewal of the intestinal cell wall, induce presentation of CD44postive cells, initiate the expression of stemness-associated genes, elevate transcriptional products of the downstream Wnt signaling of CD44, and reduce diarrhea and intestinal damage
Xiao Ai Jie Du decoction BP10A

Ge Gen Qin Lian decoction
Hedyotis diffusa and Codonopsis pilosa, Sophora flavescens, and Zingiber officinale Descurainiae sophia semen and Peucedani praeruptorum radix

Radix Puerariae, Scutellariae radix, Coptidis Rhizoma, and liquorice
Patients who fulfill the criteria HCT-116 cells KM12SM cells

$\mathrm{BALB} / \mathrm{c}$ mice
Unknown

$6.25-25 \mu \mathrm{g} / \mathrm{ml}$ $25-200 \mu \mathrm{g} / \mathrm{ml}$

$300-7500 \mathrm{mg} / \mathrm{kg}$
In vivo Unknown

In vitro Delay tumor growth and enhance the Kim et al. In vitro antitumor activity of each anticancer (2019b) drug and delay tumor growth

In vivo Enrich related intestinal microorganisms, Lv et al. increase the proportion of CD8 ${ }^{+} \mathrm{T}$ cells in (2019) peripheral blood and tumor tissues, increase the expression of IFN- $\gamma$, downregulate PD-1, and increase IL-2 levels

Zhi Zhen Fang Radix Astragali, fFructus ligustri lucidi, formula semen coicis, Salvia chinensis, Vitis quinquangularis Rehd., Actinidia arguta, and Cyperus rotundus $\mathrm{L}$.
HCT-116 cells $\quad 25-1,600 \mu \mathrm{g} / \mathrm{ml}$ HCT-8 cells Athymic mice
$25-1,600 \mu \mathrm{g} / \mathrm{ml}$ $13.27-53.08 \mathrm{~g} / \mathrm{kg}$
In vitro Enhance the sensitivity of chemotherapeutic drugs and induce In vitro apoptosis, inhibit the hedgehog
Xi et al.

(2015)

Chan et al. (2020)

(Continued on following page) 
TABLE 2 | (Continued) CMFs for anti-CRC and corresponding mechanisms.

\begin{tabular}{|c|c|c|c|c|c|c|}
\hline CMF name & Composition & $\begin{array}{l}\text { Cell lines/ } \\
\text { model }\end{array}$ & Dose & Detail & Mechanism & Ref \\
\hline & & & & & $\begin{array}{l}\text { pathway, inhibit tumor growth, and } \\
\text { reduce Gli1 levels }\end{array}$ & \\
\hline $\begin{array}{l}\text { Teng Long Bu } \\
\text { Zhong Tang }\end{array}$ & $\begin{array}{l}\text { Actinidia chinensis, Solanum nigrum, } \\
\text { Duchesnea indica, Atractylodes } \\
\text { macrocephala Koidz., Poria cocos, Coix } \\
\text { seed, mistletoe, and Scutellaria barbata }\end{array}$ & BALB/c mice & $22.5,30 \mathrm{mg} / \mathrm{kg}$ & In vivo & $\begin{array}{l}\text { Inhibit cancer cell growth, elicite } \\
\text { apoptosis, and downregulate XIAP and } \\
\text { survivin, induce cell senescence, and } \\
\text { enhance anticancer effects of 5-Fu }\end{array}$ & $\begin{array}{l}\text { Deng et al } \\
\text { (2013a) }\end{array}$ \\
\hline Wei Chang An & $\begin{array}{l}\text { Pseudostellaria heterophylla Pax., } \\
\text { Atractylodes macrocephala Koidz., Poria } \\
\text { cocos Wolf., Glycyrrhiza uralensis Fisch., } \\
\text { Sargentodoxa cuneata, and Prunella } \\
\text { vulgaris L. }\end{array}$ & HCT-116 cells & $3-9 \%$ & In vitro & $\begin{array}{l}\text { Reduce the rate of metastasis, decrease } \\
\text { the expression of } \beta \text {-catenin and MMP-7, } \\
\text { and reduce nuclear translocation of } \\
\beta \text {-catenin }\end{array}$ & $\begin{array}{l}\text { Tao et al. } \\
(2015)\end{array}$ \\
\hline
\end{tabular}

etc) have been reported. For example, Galla chinensis, a commonly used herbal medicine in East Asia, has been found to inhibit lung metastasis by inducing AMPK-mediated apoptosis and inhibiting the metastasis of CRC cells (Mun et al., 2019). Treatment of HCT116 cells, HT29 cells, SW480 cells, Caco-2 cells, and Colo205 cells with various concentrations of Antrodia cinnamomea extract resulted in a dose- and time-dependent decrease in cell viability, indicating that it may induce autophagic cell death via the CHOP/TRB3/Akt/mTOR pathway. In addition, in a nude mice model of metastatic CRC cancer, similar experimental results are also observed (Tsai et al., 2018). Another study demonstrated that the Ampelopsis ethanolic extract can suppress STAT3 and Src phosphorylation, inhibit STAT3 nuclear localization, and downregulate the expression of STAT3 target genes Mcl-1, Bcl-xL, and MMP-2 in HCT-116 and SW480 cells. These data provide a relevant scientific research basis for the traditional use of Ampelopsis radix extract for CRC and a pharmacological clue for the development of a modern anti-CRC agent (Su et al., 2017). Hedyotis diffusa, a typical Chinese herb for clearing heat and detoxification, has demonstrated that its chloroform extract can inhibit the activity of human CRC cells by inhibiting the Akt and ERK signaling pathway (Yan et al., 2017a). In SW480 and SW620 cells, Ginkgo biloba extract dose-dependently inhibited cell migration and invasion, induced upregulation of LncRNA-p21 expression, and suppressed the expression of extracellular matrix protein fibronectin (Liu et al., 2017a). Overall, the abovementioned documents suggest the TCM extract as a promising therapeutic agent for CRC in clinical settings. More detailed information concerning anti-CRC of TCM extracts is depicted in Table 3.

\section{Anti-Colorectal-Cancer Effect of Traditional Chinese Medicine Compounds}

In recent years, the compounds of TCM have attracted extensive attention in the field of pharmaceutical research, owing to their multiple pharmacological activities and unique advantages of multitarget effect. With the development of modern technology, increasing compounds in TCM have been found to have the effect of anti-CRC (Luo et al., 2019; Kwon and Chan,
2020; Tan et al., 2020). The published reports serve as a jumpingoff point for further investigation, with the potential of compounds in TCM to serve as agents for CRC. The chemical structures of the most frequently investigated TCM compounds for CRC are listed in the following (Figure 1).

\section{Berberine}

Berberine, an isoquinoline alkaloid from traditional herbal medicine Coptis chinensis, has long been applied as an overthe-counter (OTC) agent for the treatment of intestinal infections and diarrhea (Feng et al., 2019b). With the development of modern pharmacology, the anti-CRC effect of berberine has become increasingly salient (Hallajzadeh et al., 2020). A double-blind, randomized, placebo-controlled clinical trial of berberine in preventing recurrence of CRC corroborated that berberine at $300 \mathrm{mg}$ twice daily was secure and effective in abating the risk of recurrence of colorectal adenoma and might be a recommendable option for chemoprevention after polypectomy (Chen et al., 2020b). Through bioinformatics analysis and validation of related experiments, the researcher proved that berberine exerted the function of inducing G0/G1 phase arrest in HCT116 and SW480 cells by downregulating IGF2BP3 (Zhang et al., 2020c). In another study, treatment of HT-29 and SW480 cells with various concentrations $(0.5-20 \mu \mathrm{M})$ of berberine resulted in a dose-dependent decrease in sonic hedgehog mRNA and protein (Shen et al., 2020). Moreover, berberine was reported to restrain the expression of GRP78 and its localization on the cell surface in dose- and time-dependent manners, as well as suppress the expression of Bax, Bcl-2, c-Myc and elevate the cytokeratin expression in SW480 cells (Gong et al., 2020). In KM12C cells, berberine can dose dependently attenuate $\beta$-catenin function through directly binding to a unique region comprising residues $\mathrm{G} \ln 275$, Arg316, and Arg371 in nuclear receptor RXRa. Intraperitoneal injection of berberine also hindered the growth of human colon carcinoma xenograft in BALB/c mice with an RXRa-dependent manner (Ruan et al., 2017). In addition, the anti-CRC effect of berberine may be attributed to its promotion of apoptosis (Dai et al., 2019b), regulation of the tumor microenvironment ( $\mathrm{Yu}$ et al., 2015), and regulation of specific long noncoding RNA (LncRNA) (Dai et al., 2019c). In general, the abovementioned 
TABLE 3 | Anti-CRC effect and mechanism of TCM extract.

\begin{tabular}{|c|c|c|c|c|c|c|}
\hline Extract type & Source & Cell lines/model & Dose & Detail & Mechanism & Ref \\
\hline Aqueous extract & Galla Rhois & $\begin{array}{l}\text { HT } 29 \text { cells } \\
\text { CT } 26 \text { cells } \\
\text { BALB/c mice }\end{array}$ & $\begin{array}{l}20-100 \mu \mathrm{g} / \mathrm{ml} \\
20-100 \mu \mathrm{g} / \mathrm{ml} \\
200,500 \mathrm{mg} / \mathrm{kg}\end{array}$ & $\begin{array}{l}\text { In vitro } \\
\text { In vitro } \\
\text { In vivo }\end{array}$ & $\begin{array}{l}\text { Inhibit lung metastasis by inducing AMPK-mediated } \\
\text { apoptosis and suppressing metastatic properties of } \\
\text { colorectal cancer cells }\end{array}$ & $\begin{array}{l}\text { Mun et al. } \\
(2019)\end{array}$ \\
\hline- & Ginkgo biloba & $\begin{array}{l}\text { SW } 480 \text { cells } \\
\text { SW } 620 \text { cells }\end{array}$ & $\begin{array}{l}200,500 \mathrm{mg} / \mathrm{ml} \\
200,500 \mathrm{mg} / \mathrm{ml}\end{array}$ & $\begin{array}{l}\text { In vitro } \\
\text { In vitro }\end{array}$ & $\begin{array}{l}\text { Inhibit migration and invasion, induce upregulation } \\
\text { of LncRNA-p21 expression, and inhibit the } \\
\text { expression of extracellular matrix protein fibronectin }\end{array}$ & $\begin{array}{l}\text { Liu et al. } \\
\text { (2017a) }\end{array}$ \\
\hline- & $\begin{array}{l}\text { Medicinal } \\
\text { mushroom }\end{array}$ & $\begin{array}{l}\text { HCT } 116 \text { cells } \\
\text { SW } 620 \text { cells } \\
\text { BALB/c mice }\end{array}$ & $\begin{array}{l}1.332-13.32 \mu \mathrm{g} / \mathrm{ml} \\
1.332-13.32 \mu \mathrm{g} / \mathrm{ml} \\
400,1,200 \mathrm{mg} / \mathrm{kg}\end{array}$ & $\begin{array}{l}\text { In vitro } \\
\text { In vitro } \\
\text { In vivo }\end{array}$ & $\begin{array}{l}\text { Inhibit cell proliferation and promote cell apoptosis, } \\
\text { inhibit tumor growth, and inhibit VEGF and MMP-2 } \\
\text { and MMP-9 modulation }\end{array}$ & $\begin{array}{l}\text { Jakopovic } \\
\text { et al. (2020) }\end{array}$ \\
\hline- & Pogostemon cablin & $\begin{array}{l}\text { HT } 29 \text { cells } \\
\text { CT } 26 \text { cells } \\
\text { BALB/c mice }\end{array}$ & $\begin{array}{l}5.83-93.2 \mu \mathrm{g} / \mathrm{ml} \\
5.83-93.2 \mu \mathrm{g} / \mathrm{ml} \\
200 \mathrm{mg} / \mathrm{kg}\end{array}$ & $\begin{array}{l}\text { In vitro } \\
\text { In vitro } \\
\text { In vivo }\end{array}$ & $\begin{array}{l}\text { Decrease viability, inhibit proliferation and induce cell } \\
\text { cycle arrest at the } G_{0} / G_{1} \text { phase and apoptosis, and } \\
\text { suppress growth of } C R C\end{array}$ & $\begin{array}{l}\text { Chien et al. } \\
\text { (2020) }\end{array}$ \\
\hline- & Scutellaria barbata & Nude mice & $615,1230 \mathrm{mg} / \mathrm{kg}$ & In vivo & $\begin{array}{l}\text { Regulate the expressions of related proteins } \\
\text { E-cadherin, Tspan } 8 \text { and CXCR4, and Src kinase } \\
\text { and reduce orthotopic tumor burden }\end{array}$ & $\begin{array}{l}\text { Yue et al. } \\
(2020)\end{array}$ \\
\hline- & $\begin{array}{l}\text { Cudrania } \\
\text { tricuspidata leaf }\end{array}$ & C57BL/6 J mice & $1.5 \mathrm{~g} / \mathrm{kg}$ & In vivo & $\begin{array}{l}\text { Reduce the risk of colitis-associated colon cancer } \\
\text { via the regulation of inflammation, carcinogenesis, } \\
\text { and compositional change of gut microbiota }\end{array}$ & $\begin{array}{l}\text { Oh et al. } \\
(2020)\end{array}$ \\
\hline- & Solanum nigrum leaf & $\begin{array}{l}\text { HT } 29 \text { cell } \\
\text { DLD-1 cells }\end{array}$ & $\begin{array}{l}0.05-5 \mathrm{mg} / \mathrm{ml} \\
0.05-5 \mathrm{mg} / \mathrm{ml}\end{array}$ & $\begin{array}{l}\text { In vitro } \\
\text { In vitro }\end{array}$ & $\begin{array}{l}\text { Induce autophagy via microtubule-associated } \\
\text { protein } 1 \text { light chain } 3 \mathrm{~A} / \mathrm{B} \| \text { accumulation and } \\
\text { enhance cytotoxicity in tumor cells }\end{array}$ & Tai et al. (2013) \\
\hline- & Pulsatillae Radix & SW 480 cells & $5-20 \mu \mathrm{g} / \mathrm{ml}$ & In vitro & $\begin{array}{l}\text { Inhibit invasion and migration and block the S phase } \\
\text { in the cell cycle }\end{array}$ & $\begin{array}{l}\text { Zhang et al. } \\
\text { (2019b) }\end{array}$ \\
\hline Ethanol extract & $\begin{array}{l}\text { Antrodia } \\
\text { cinnamomea }\end{array}$ & $\begin{array}{l}\text { HCT } 116 \text { cells HT } \\
29 \text { cells } \\
\text { SW } 480 \text { cells } \\
\text { Caco- } 2 \text { cells Colo } \\
205 \text { cells }\end{array}$ & $\begin{array}{l}50-200 \mu \mathrm{g} / \mathrm{ml} \\
50-200 \mu \mathrm{g} / \mathrm{ml} \\
50-200 \mu \mathrm{g} / \mathrm{ml} \\
50-200 \mu \mathrm{g} / \mathrm{ml} \\
50-200 \mu \mathrm{g} / \mathrm{ml} \\
100-400 \mathrm{mg} / \mathrm{kg}\end{array}$ & $\begin{array}{l}\text { In vitro } \\
\text { In vitroln } \\
\text { vitro } \\
\text { In vitro } \\
\text { In vitro }\end{array}$ & $\begin{array}{l}\text { Upregulate expression of the endoplasmic reticulum } \\
\text { stress marker CHOP and its downstream gene } \\
\text { TRB3 and induce autophagic cell death and } \\
\text { dephosphorylation of Akt and mTOR. }\end{array}$ & $\begin{array}{l}\text { Tsai et al. } \\
\text { (2018) }\end{array}$ \\
\hline- & Ampelopsis radix & $\begin{array}{l}\text { HCT } 116 \text { cells SW } \\
480 \text { cells }\end{array}$ & $\begin{array}{l}50-600 \mu \mathrm{g} / \mathrm{ml} \\
50-600 \mu \mathrm{g} / \mathrm{ml}\end{array}$ & $\begin{array}{l}\text { In vitro } \\
\text { In vitro }\end{array}$ & $\begin{array}{l}\text { Suppress STAT3 and Src phosphorylation, inhibit } \\
\text { STAT3 nuclear localization, and downregulate the } \\
\text { expression of STAT3 target genes } \mathrm{Mcl}-1, \mathrm{Bcl}-\mathrm{xL} \text {, } \\
\text { and MMP-2 }\end{array}$ & Su et al. (2017) \\
\hline- & $\begin{array}{l}\text { Hedyotis diffusa } \\
\text { Willd. }\end{array}$ & HT 29 cells & $0.5-2 \mathrm{mg} / \mathrm{ml}$ & In vitro & $\begin{array}{l}\text { Downregulate the expression of leucine-rich repeat- } \\
\text { containing G-protein-coupled receptor } 5 \text { and } \\
\text { decrease the proportion of SP, inhibit viability and } \\
\text { sphere formation, induce cell morphological } \\
\text { changes, and suppress messenger RNA expression } \\
\text { of several critical genes }\end{array}$ & $\begin{array}{l}\text { Sun et al. } \\
(2016)\end{array}$ \\
\hline- & $\begin{array}{l}\text { Hedyotis diffusa } \\
\text { Willd. }\end{array}$ & BABL/c mice & $6 \mathrm{~g} / \mathrm{kg}$ & In vivo & $\begin{array}{l}\text { Reduce tumor volume and weight, suppress STAT3 } \\
\text { phosphorylation, alter expression pattern of target } \\
\text { genes, and decrease cyclin D1, CDK4, and Bcl-2 }\end{array}$ & $\begin{array}{l}\text { Cai et al. } \\
(2012)\end{array}$ \\
\hline $\begin{array}{l}\text { Methanolic } \\
\text { extract }\end{array}$ & Emilia sonchifolia & $\begin{array}{l}\text { HCT } 116 \text { cells } \\
\text { HT } 29 \text { cells } \\
\text { SW } 480 \text { cells }\end{array}$ & $\begin{array}{l}25-100 \mu \mathrm{g} / \mathrm{ml} \\
25-100 \mu \mathrm{g} / \mathrm{ml} \\
25-100 \mu \mathrm{g} / \mathrm{ml}\end{array}$ & $\begin{array}{l}\text { In vitro } \\
\text { In vitro } \\
\text { In vitro }\end{array}$ & $\begin{array}{l}\text { Inhibit cell growth, induce apoptosis, promote the } \\
\text { mitochondria-dependent and death-receptor- } \\
\text { associated protein levels, increase ROS production, } \\
\text { and upregulate ATM, p53, and Fas }\end{array}$ & $\begin{array}{l}\text { Lan et al. } \\
(2012)\end{array}$ \\
\hline- & $\begin{array}{l}\text { Artemisia } \\
\text { absinthium }\end{array}$ & HCT 116 cells & $100-1,000 \mu \mathrm{g} / \mathrm{ml}$ & In vitro & $\begin{array}{l}\text { Reduce viability, increase the mRNA and protein } \\
\text { levels of Bax, decrease BCL-2, prompt cell cycle } \\
\text { arrest, and induce apoptosis by activating the } \\
\text { mitochondrial pathway }\end{array}$ & $\begin{array}{l}\text { Nazeri et al. } \\
(2020)\end{array}$ \\
\hline- & $\begin{array}{l}\text { Muntingia } \\
\text { calabura L. }\end{array}$ & Wistar rats & $100,200 \mathrm{mg} / \mathrm{kg}$ & In vivo & $\begin{array}{l}\text { Cause antioxidant enzymic levels to retain near to its } \\
\text { normal range and reduce severity of colorectal } \\
\text { cancer }\end{array}$ & $\begin{array}{l}\text { Jisha et al. } \\
(2020)\end{array}$ \\
\hline- & $\begin{array}{l}\text { Immature fruit of } \\
\text { Poncirus trifoliata }\end{array}$ & $\begin{array}{l}\text { CT- } 26 \text { cells HCT- } \\
116 \text { cells DLD- } 1 \\
\text { cells }\end{array}$ & $\begin{array}{l}1-20 \mu \mathrm{M} \\
1-20 \mu \mathrm{M} \\
1-20 \mu \mathrm{M}\end{array}$ & $\begin{array}{l}\text { In vitro } \\
\text { In vitro } \\
\text { In vitro }\end{array}$ & $\begin{array}{l}\text { Inhibit proliferation and induce autophagy and } \\
\text { apoptosis by protein kinase B/mammalian target of } \\
\text { rapamycin and } 5^{\prime} \text {-AMP-activated protein kinase } \\
\text { pathways }\end{array}$ & $\begin{array}{l}\text { Kim et al. } \\
(2020)\end{array}$ \\
\hline $\begin{array}{l}\text { Chloroform } \\
\text { extract }\end{array}$ & $\begin{array}{l}\text { Hedyotis diffusa } \\
\text { Willd. }\end{array}$ & $\begin{array}{l}\text { SW } 620 \text { cells } \\
\text { HT } 29 \text { cells } \\
\text { HCT } 116 \text { cells } \\
\text { HCT } 8 \text { cells } \\
\text { HCT } 8 \text { cells }\end{array}$ & $\begin{array}{l}150-500 \mu \mathrm{g} / \mathrm{ml} \\
150-500 \mu \mathrm{g} / \mathrm{ml} \\
150-500 \mu \mathrm{g} / \mathrm{ml} \\
150-500 \mu \mathrm{g} / \mathrm{ml} \\
50-300 \mu \mathrm{g} / \mathrm{ml}\end{array}$ & $\begin{array}{l}\text { In vitro } \\
\text { In vitro } \\
\text { In vitro } \\
\text { In vitro } \\
\text { In vitro }\end{array}$ & $\begin{array}{l}\text { Inhibit proliferation and promote apoptosis, } \\
\text { downregulate the survivin, proliferating cell nuclear } \\
\text { antigen, cyclin-dependent kinase } 4 \text {, and } \mathrm{Bcl}-2 \text {, and } \\
\text { upregulate Bcl-2-associated X protein }\end{array}$ & $\begin{array}{l}\text { Jakopovic } \\
\text { et al. (2020) }\end{array}$ \\
\hline
\end{tabular}


TABLE 3 | (Continued) Anti-CRC effect and mechanism of TCM extract.

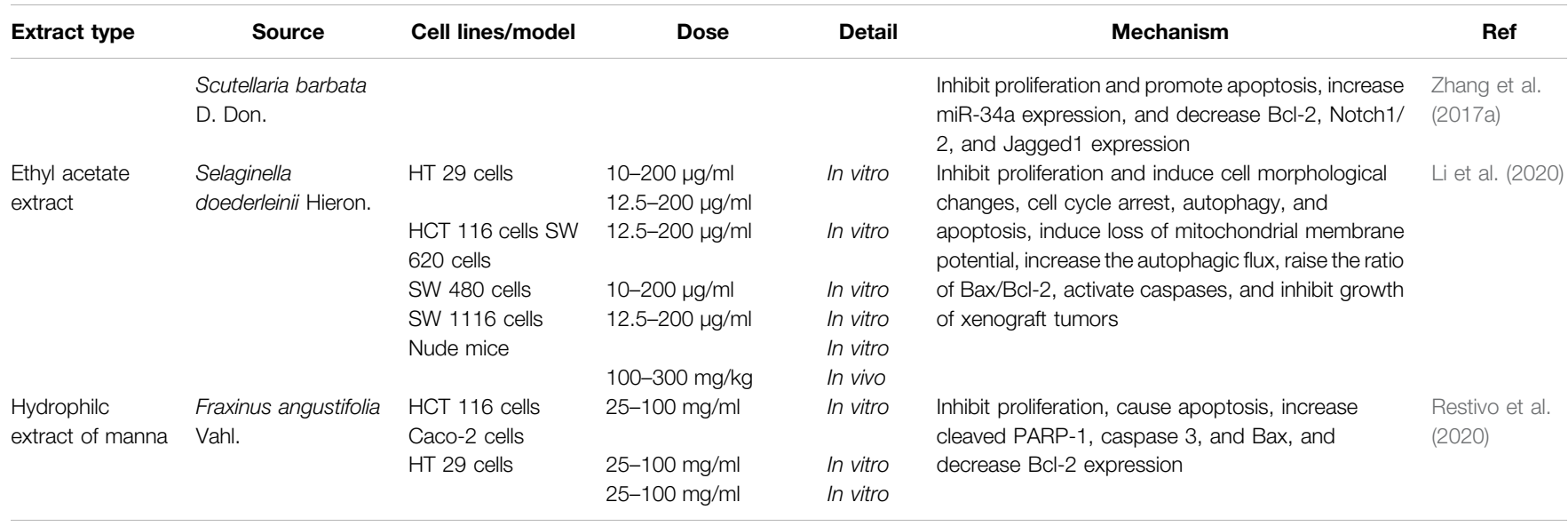

reports suggest that berberine may be a promising therapeutic agent for the treatment of CRC.

\section{Evodiamine}

Evodiamine, a naturally occurring alkaloid with quinazolinocarboline skeleton, originates from numerous herbs including Evodia rutaecarpa (Liu et al., 2019b) and Euonymus europaeus (Sevastre et al., 2017). In recent years, there have been increasing studies on its anti-CRC effect (Sun et al., 2020b). Evodiamine suppressed the proliferation of CRC cells HT29, HCT15, and SW480 and induced apoptosis by cell cycle arrest in the $G_{2} / M$ phase, as well as suppressed the expression of cancerstem-cell-related genes (Kim et al., 2019a). Moreover, it inhibited metastasis and invasion of CRC through regulating Sirt1mediated translation in cell and Balb/c mice models (Zhou et al., 2019b). Additionally, evodiamine suppressed the LoVo cells proliferation and promoted apoptosis and lessened HIF-1a either in vitro or in vivo, as well as decreased the phosphorylation of Akt1/2/3 and the expression of IGF-1 (Huang et al., 2015). In another report, evodiamine was found to be effective in decreasing the expression level of miR-429 in CRC patient tissue (Liu et al., 2016). Furthermore, evodiamine regulated the activity of the p53 signaling pathway to promote the apoptosis of human CRC cells HCT116 and lower the MMP3 expression via deactivating the JAK2/STAT3 pathway by the reduction of PGI to suppress migration of cancer cells and decrease the levels of the secreted form of autocrine motility factor (AMF) (Zhao et al., 2015). In combination therapy, evodiamine could inhibit multidrug resistance of HCT116 cells by blocking the p50/p65-NF-kappa-B signaling pathway (Sui et al., 2016). These works provide direct evidence for the antiCRC effect of evodiamine and also indicate that it may be a potential candidate agent for the treatment of this malignant tumor.

\section{Curcumin}

Curcumin is a kind of acidic polyphenols compound extracted from the rhizomes of Curcuma longa L. Growing experimental evidence indicates that curcumin exhibits multitarget biological activities in disease prevention and treatment (Patel et al., 2020). In recent years, curcumin, as a natural anticancer agent (Mortezaee et al., 2019; Tomeh et al., 2019), especially for CRC (Gupta et al., 2019), has captured the attention of pharmaceutical researchers. It was documented that curcumin can abate the viability and proliferation of HCT-116 cells, suppress its migration and invasion to the lung in the mice model, and augment the mRNA and protein levels of apoptosisrelated genes (FAS, FADD, caspase-8, and caspase-3) and E-cadherin (Xiang et al., 2020). Furthermore, curcumin suppresses tumor growth in colitis-associated CRC and the proliferation and invasive behavior in CT26 cells by the modulation of the Wnt pathway and E-cadherin. Fortunately, curcumin also exhibited a similar anti-CRC effect on the C57BL/6 mice model (Marjaneh et al., 2018b). Moreover, the use of curcumin accelerated ROS-mediated cell death at $40 \mu \mathrm{M}$ in the mutated p53 and wild-type p53 colon adenocarcinoma cell lines in vitro (Sritharan and Sivalingam, 2021). Moreover, curcumin attenuated tumor EMT by blocking the Wnt signaling pathway and elevating the expression level of naked cuticle homolog 2 (NKD2) in SW620 cells (Zhang et al., 2016). Additionally, curcumin could also exert an anti-CRC effect through epigenetic (Wu et al., 2020) and covalent modification of cysteine 67 residue of SIRT1 (Lee et al., 2018a). Given that resistance of cancer cells to chemotherapeutic agents has been recognized in clinical settings, in recent years, curcumin combined with other chemotherapeutic agents to ameliorate the drug resistance of tumor cells has become paramountly vital. A recent work has provided compelling evidence that curcumin could moderate the expression level of the excision repair cross-complementing gene (ERCC1) and sharply increase oxaliplatin sensitivity in resistant human CRC cells HCT116 through its effects on miR-409-3p (Han et al., 2020). In addition, curcumin could also retard the EMT process by regulating the TET1-NKD-Wnt signaling pathway and then reverse 5-FU resistance of colon cancer cells HCT116 (Lu et al., 2020b), as well as reinforce cisplatin resistance of colon cancer cells HCT 8 by targeting LncRNA-KCNQ1OT1 (Zheng et al., 2021). These effects of curcumin may provide a positive 
<smiles></smiles>

Berberine<smiles>CN1c2ccccc2C(=O)N2CCc3c([nH]c4ccccc34)C21</smiles>

Evodiamine<smiles>O=C1CCC[C@]23CCCCN2CC2CCCN4CC12C43</smiles>

Matrine

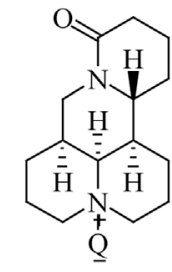

Oxymatrine<smiles>Cc1coc2c1C(=O)C(=O)c1c-2ccc2c1CCCC2(C)C</smiles>

Tanshinone II A<smiles>C[C@]12C3=C[C@H](O)C[C@@H]1c1cc4c(cc1CN2CC3)OCO4</smiles>

Lycorine<smiles>O=C1CCC[C@H]2C3CCCN4CC[C@@H](C[C@H]34)CN12</smiles>

Sophoridine<smiles>Cc1cc(O)c2c(c1)C(=O)c1cc(O)cc(O)c1C2=O</smiles>

Emodin<smiles>COc1ccc(C(C)=O)c(O)c1</smiles>

Paeonol<smiles>CC(C)=CC[C@@H](O)C1=CC(=O)c2c(O)ccc(O)c2C1=O</smiles>

Shikonin<smiles>Oc1ccc(/C=C/c2cc(O)cc(O)c2)cc1</smiles>

Resveratrol<smiles>O=c1c(-c2ccc(O)cc2)coc2cc(O)cc(O)c12</smiles>

Genistein<smiles>O=c1c(O)c(-c2ccc(O)c(O)c2)oc2cc(O)cc(O)c12</smiles>

Quercetin<smiles>O=c1cc(-c2ccc(O)c(O)c2)oc2cc(O)cc(O)c12</smiles>

Luteolin<smiles></smiles>

Coptisine<smiles>Nc1ncnc2c1ncn2[C@H]1O[C@@H](CO)C[C@H]1O</smiles>

Cordycepin<smiles>O=C(O)[C@H]1O[C@@H](Oc2cc3oc(-c4ccccc4)cc(=O)c3c(O)c2O)[C@H](O)[C@@H](O)[C@@H]1O</smiles>

Baicalin<smiles>C=C1CC[C@H]2[C@@H](CO)C(O)CC[C@]2(C)[C@H]1C/C=C1\C(=O)OC[C@H]1O</smiles>

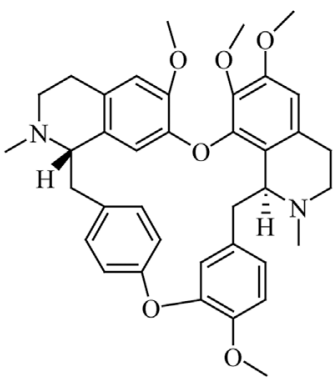

Andrographolide Tetrandrine<smiles>O=C(/C=C/c1ccc2c(c1)OCO2)N1CCCCC1</smiles>

Piperine<smiles>COc1cc(/C=C/C(=O)/C=C(O)/C=C/c2ccc(O)c(OC)c2)ccc1O</smiles>

Curcumin

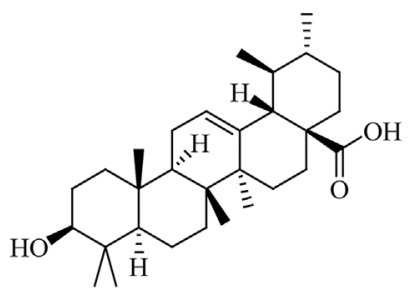

Ursolic acid

FIGURE 1 | Chemical structures of TCM-derived compounds for CRC.

avenue for future research and development of novel agents for CRC.

\section{Resveratrol}

Resveratrol is a kind of natural nonflavonoid polyphenols existing in Polygonum cuspidatum, grape, and other herbs. It possesses antioxidant, anti-inflammatory, antishock, and other biological activities and owns a favorable protective effect on the cardiovascular and nervous system (Tian and Liu, 2020). Intriguingly, in the past few decades, its widespread consumption has been reported to work as a cancer preventative approach in several epidemiological studies (Rauf 
et al., 2018; Singh et al., 2019; Verdura et al., 2020), especially the CRC (Li et al., 2019a). It was reported that resveratrol at $5 \mu \mathrm{M}$ suppressed TNF-beta-promoted NF- $\kappa B$-mediated gene biomarkers linked with proliferation, apoptosis, and invasion, as well as lessened TNF-beta/TNF-beta-receptor-mediated inflammatory response in human CRC cells HCT116 in vitro (Buhrmann et al., 2019). Another study revealed that there was a statistically significant reduction of cell number and increase in the percentage of apoptosis in CRC cells treated with resveratrol at 1-100 $\mu \mathrm{M}$ (San Hipolito-Luengo et al., 2017). In a study on the effect of resveratrol on CRC metastasis, the authors speculated that resveratrol, with its ability to induce the expression of RKIP at protein levels, may provide a novel option for revealing the structural arrangements during drug-target interactions (Dariya et al., 2020). Furthermore, HCT116 and SNU81 cells treated with various concentrations of resveratrol illustrated inhibition on the proliferation and invasion/metastasis via activating tristetraprolin (TPP) (Lee et al., 2018b). The rapid metastasis of CRC, which has a strong link with the invasion degree of cancer cells, can reportedly be undermined by resveratrol through regulating cancer cell invasion via the modulation of the levels of focal adhesion molecules (Buhrmann et al., 2017). Resveratrol also induced $\mathrm{p} 53$ in CRC through elevating the expression of SET domain containing lysine methyltransferase 7/9 (SET7/9) (Liu et al., 2019a). Also, consistent with its long-standing antioxidant effect, resveratrol has been shown to exhaust the level of thiobarbituric acid reactive substances in blood serum and retard the development of the tumor, in a SD rat model of colon cancer (Rytsyk et al., 2020). In addition to these mechanisms mentioned above, resveratrol could also engender the anti-CRC effect via inhibiting cross talk between CRC cells and stromal cells in the multicellular tumor microenvironment (Buhrmann et al., 2020) and reversing the drug resistance of chemotherapy (Huang et al., 2019). As a whole, future studies on the anti-CRC effect of resveratrol will be highly interesting, if these effects can be repeated in other CRC models.

\section{Quercetin}

Quercetin is a natural flavonoid with outstanding biological activity. Research over the past few decades has corroborated that this functional dietary flavone possesses vast pharmacological activities, such as antioxidant, antiinflammatory, bone protection, cardiovascular protection (Almeida et al., 2018; Huang et al., 2020a; Wong et al., 2020). Interestingly, recent studies have hinted that quercetin may be effective for the prevention and treatment of CRC (Darband et al., 2018; Pang et al., 2019). For example, quercetin inhibited azoxymethane/dextran sulfate sodium(AOM/DSS-) induced colon carcinogenesis in the C57BL/6J mice model through abating the expression of oxidative stress markers, such as lipid peroxide (LPO), nitric oxide (NO), superoxide dismutase (SOD), glucose-6-phosphate (G6PD), and glutathione (GSH) (Lin et al., 2020). Besides, quercetin alleviated colon damage and lessened the mortality rate in CRC mice, suppressed the TNF- $\alpha$ level, raised the relative abundance of Parabacteroides, and decreased the gene of Hmgcs2, Fabp2, and Gpt (Qi et al., 2019). Quercetin also preferentially promotes apoptosis in KRAS-mutant CRC cells via JNK signaling pathways (Yang et al., 2019b). Based on the model of BALB/ c mice with metastatic CRC, quercetin remarkably hindered lung metastasis of CRC CT26 cells. Also, it blocked the migration and invasion of CT26 cells by regulating the expression of MMPs and tissue inhibitors of metalloproteinases (TIMPs) (Kee et al., 2016). In another study, quercetin inhibited the viability of HT29 cells, caused cell shrinkage, chromatin condensation, and nuclear collapse, lessened the protein expression levels of phosphorylated-Akt, and augmented the protein degradation of constitutive photomorphogenesis 6 signalosome (CSN6) (Yang et al., 2016). Furthermore, quercetin was known to be efficient at facilitating the expression of Slpi (secretory leukoprotease inhibitor) that in turn reduced the inflammatory response in vivo (De Santis et al., 2016). Quercetin is a logical botanical ingredient for future treatment of CRC and may be a beneficial addition to the development of other agents for CRC.

\section{Shikonin}

Shikonin is a naphthoquinone compound extracted from traditional Chinese herbal medicine Lithospermum erythrorhizon Sieb.et Zucc., which has anti-inflammatory, antioxidation, antitumor, wound healing promoting, and other effects (Guo et al., 2019). In recent years, the antitumor effect of shikonin has been extensively investigated. A multitude of in vitro and in vivo experiments have indicated that it can effectively curb the occurrence and development of breast cancer, cervical cancer, CRC, and so on (Fan et al., 2012; Tang et al., 2020; Bao et al., 2021). The study on the potential target, molecular mechanism, and antitumor effect of shikonin against CRC in vivo and in vitro demonstrated that it facilitated human CRC cells apoptosis and autophagy through targeting the galectin-1 and JNK signaling pathway, which delineated a promising and potential novel therapy for CRC (Zhang et al., 2020a). A study regarding the effect of shikonin on the early inflammation model of colon cancer induced by AOM/DSS demonstrated that it could protect the intestinal tissue of animals by hindering the shortening of the colorectum and ulcer formation and abate the expression of cyclooxygenase- 2 and inducible nitric oxide synthase, as well as suppress the production of interleukin- 6 and activation of nuclear factor-B (Andujar et al., 2018). In another study, the researcher argued that shikonin promoted ROS-based mitochondria-mediated apoptosis in the colon cancer cells SW480 and HCT116. Also, comfortingly, shikonin showed minimal toxicity to nonneoplastic colon cells and no liver injury in $\mathrm{BALB} / \mathrm{c}$ nude mice xenograft models, suggesting pleasurable safety in the treatment of CRC (Liang et al., 2017). Additionally, the effects of shikonin on the survival and tumor growth of the nude mice model, as well as the migration and invasion of human CRC cells, appear to be able to imply the fact that shikonin inhibited the metastasis of CRC through SIRT2(silent information regulators 2-) mediated antitumor effect (Zhang et al., 2017b). Furthermore, the anti-CRC activity of shikonin was also validated by the approaches of metabolomics, transcriptomics, and proteomics (Chen et al., 2020c; Chen et al., 2020d). In short, shikonin is a potentially 
TABLE 4 | Anti-CRC effect and mechanism of TCM compounds.

\begin{tabular}{|c|c|c|c|c|c|c|}
\hline Compound name & Main source & Cell lines/model & Dose & Detail & Mechanism & Ref \\
\hline Berberine & Coptis chinensis & HCA 7 cells & $10-100 \mu \mathrm{M}$ & In vitro & $\begin{array}{l}\text { Result in a downregulation of } 33 \text { genes differently } \\
\text { involved in cell cycle, differentiation and EMT }\end{array}$ & $\begin{array}{l}\text { Palmieri et al. } \\
(2019)\end{array}$ \\
\hline Evodiamine & Evodia rutaecarpa & НCT 116 cells & $5-15 \mu \mathrm{M}$ & In vitro & $\begin{array}{l}\text { Inhibit the proliferation of cells, cause accumulation of } \\
\text { cells in S and G2/M phases, and reduce the levels of } \\
\text { the secreted form of AMF }\end{array}$ & $\begin{array}{l}\text { Zhao et al. } \\
(2015)\end{array}$ \\
\hline Matrine & $\begin{array}{l}\text { Sophora } \\
\text { flavescens }\end{array}$ & $\begin{array}{l}\text { SW } 480 \text { cells } \\
\text { SW } 620 \text { cells }\end{array}$ & $\begin{array}{l}0.25-1.25 \mathrm{mM} \\
0.25-1.25 \mathrm{mM}\end{array}$ & $\begin{array}{l}\text { In vitro } \\
\text { In vitro }\end{array}$ & $\begin{array}{l}\text { Trigger cell apoptosis and G0/G1 cell cycle arrest via } \\
\text { mediation of microRNA-22 }\end{array}$ & $\begin{array}{l}\text { Liu et al. } \\
\text { (2020a) }\end{array}$ \\
\hline Oxymatrine & $\begin{array}{l}\text { Sophora } \\
\text { flavescens }\end{array}$ & RKO cells & $0.125-8 \mathrm{mg} / \mathrm{ml}$ & In vitro & $\begin{array}{l}\text { Inhibit the migration of human colorectal carcinoma via } \\
\text { the inhibition of PAl- } 1 \text { and the TGF- } \beta 1 / \text { Smad signaling } \\
\text { pathway }\end{array}$ & $\begin{array}{l}\text { Wang et al. } \\
(2017)\end{array}$ \\
\hline Coptisine & Coptis chinensis & $\begin{array}{l}\text { HCT } 116 \text { cells } \\
\text { BALB/c mice }\end{array}$ & $\begin{array}{l}2.81-140.54 \mu \mathrm{M} \\
50-150 \mathrm{mg} / \mathrm{kg}\end{array}$ & $\begin{array}{l}\text { In vitro } \\
\text { In vivo }\end{array}$ & $\begin{array}{l}\text { Induce apoptosis of cells by the PI3K/Akt and } \\
\text { mitochondrial-related apoptosis pathway }\end{array}$ & $\begin{array}{l}\text { Han et al. } \\
(2018)\end{array}$ \\
\hline Lycorine & Lycoris plants & $\begin{array}{l}\text { RKO cells } \\
\text { SW } 480 \text { cells }\end{array}$ & $\begin{array}{l}10-50 \mu \mathrm{M} \\
10-50 \mu \mathrm{M}\end{array}$ & $\begin{array}{l}\text { In vitro } \\
\text { In vitro }\end{array}$ & $\begin{array}{l}\text { Induce the activation of the caspase-dependent } \\
\text { mitochondrial apoptotic pathway }\end{array}$ & $\begin{array}{l}\text { Wu et al. } \\
(2018)\end{array}$ \\
\hline Piperine & Piper longum L. & HT 29 cells & $\begin{array}{l}1.25 \text { and } \\
2.5 \mu \mathrm{g} / \mathrm{ml}\end{array}$ & In vitro & $\begin{array}{l}\text { Enhance radiosensitization by inducing the cells to } \\
\text { apoptosis }\end{array}$ & $\begin{array}{l}\text { Shaheer et al. } \\
\text { (2020) }\end{array}$ \\
\hline Sophoridine & $\begin{array}{l}\text { Sophora } \\
\text { alopecuroide }\end{array}$ & $\begin{array}{l}\text { HCT } 116 \text { cells } \\
\text { SW } 480 \text { cells } \\
\text { RKO cells }\end{array}$ & $\begin{array}{l}40-160 \mu \mathrm{M} \\
40-160 \mu \mathrm{M} \\
40-160 \mu \mathrm{M}\end{array}$ & $\begin{array}{l}\text { In vitro } \\
\text { In vitro } \\
\text { In vitro }\end{array}$ & $\begin{array}{l}\text { Inhibits human colorectal cancer progression via } \\
\text { targeting the MAPKAPK2 }\end{array}$ & $\begin{array}{l}\text { Wang et al. } \\
(2019)\end{array}$ \\
\hline Tetrandrine & $\begin{array}{l}\text { Stephaniae } \\
\text { tetrandrae radix }\end{array}$ & SW620 cells & $0.2-50 \mu \mathrm{M}$ & In vitro & $\begin{array}{l}\text { Suppress adhesion, migration, and invasion via the } \\
\text { inhibition of nuclear factor-kappa B, MMP-2, and } \\
\text { MMP-9 }\end{array}$ & $\begin{array}{l}\text { Juan et al. } \\
\text { (2018) }\end{array}$ \\
\hline Vinblastine & $\begin{array}{l}\text { Catharanthus } \\
\text { roseus }\end{array}$ & $\begin{array}{l}\text { HCT } 116 \text { cells } \\
\text { BALB/c mice }\end{array}$ & $\begin{array}{l}0.3-2.5 \mathrm{nM} \\
0.25 \mathrm{mg} / \mathrm{kg}\end{array}$ & $\begin{array}{l}\text { In vitro } \\
\text { In vivo }\end{array}$ & $\begin{array}{l}\text { Inhibit tumor growth and promote angiogenesis } \\
\text { factors }\end{array}$ & $\begin{array}{l}\text { Auyeung } \\
\text { et al. (2014) }\end{array}$ \\
\hline Homoharringtonine & $\begin{array}{l}\text { Cephalotaxus } \\
\text { fortunei }\end{array}$ & $\begin{array}{l}\text { LoVo cells SW480 } \\
\text { cells Caco- } 2 \text { cells } \\
\text { BALB/C mice }\end{array}$ & $\begin{array}{l}0.1-0.4 \mu \mathrm{M} \\
0.1-0.4 \mu \mathrm{M} \\
0.1-0.4 \mu \mathrm{M} \\
0.25-1 \mathrm{mg} / \mathrm{kg}\end{array}$ & $\begin{array}{l}\text { In vitro } \\
\text { In vitro } \\
\text { In vitro } \\
\text { In vivo }\end{array}$ & $\begin{array}{l}\text { Suppress cell growth by inhibiting EphB4 and the } \\
\text { PI3K/AKT and MAPK/EKR1/2 signaling pathways }\end{array}$ & $\begin{array}{l}\text { Shi et al. } \\
(2020)\end{array}$ \\
\hline Curcumin & Curcuma longa L. & $\begin{array}{l}\text { HCT } 8 \text { cells } \\
\text { Nude mice }\end{array}$ & $\begin{array}{l}10 \mu \mathrm{M} \\
1 \mathrm{~g} / \mathrm{kg} / \text { week }\end{array}$ & $\begin{array}{l}\text { In vitro } \\
\text { In vivo }\end{array}$ & $\begin{array}{l}\text { Downregulate KCNQ1OT1 expression, thus reversing } \\
\text { cisplatin resistance in CRC cells }\end{array}$ & $\begin{array}{l}\text { Zheng et al. } \\
(2021)\end{array}$ \\
\hline Resveratrol & Veratrum Linn. & $\begin{array}{l}\text { DLD-1 cells Caco-2 } \\
\text { cells }\end{array}$ & $\begin{array}{l}40-120 \mu \mathrm{M} \\
40-120 \mu \mathrm{M}\end{array}$ & $\begin{array}{l}\text { In vitro } \\
\text { In vitro }\end{array}$ & $\begin{array}{l}\text { Regulate several genes involved in the modulation of } \\
\text { apoptosis such as PMAIP1, BID, and ZMAT3 }\end{array}$ & $\begin{array}{l}\text { Gavrilas et al. } \\
(2019)\end{array}$ \\
\hline Quercetin & $\begin{array}{l}\text { Sophora } \\
\text { japonica L. }\end{array}$ & Wistar rats & 50 mg/kg & In vivo & $\begin{array}{l}\text { Suppress DNA damage and induce DNA repair and } \\
\text { increase the levels and activities of enzymic, as well as } \\
\text { the nonenzymic antioxidants }\end{array}$ & $\begin{array}{l}\text { Darband et al. } \\
(2020)\end{array}$ \\
\hline Tanshinone II A & $\begin{array}{l}\text { Salvia } \\
\text { miltiorrhiza Bge. }\end{array}$ & SW 620 cells & $0.5-10 \mu \mathrm{g} / \mathrm{ml}$ & In vitro & Suppress SW620 proliferation and induce apoptosis & $\begin{array}{l}\text { Xue et al. } \\
(2019)\end{array}$ \\
\hline Luteolin & Reseda odorata & $\begin{array}{l}\text { HT- } 29 \text { cells SW } 480 \\
\text { cells SW620 cells } \\
\text { LoVo cells } \\
\text { BALB/c mice }\end{array}$ & $\begin{array}{l}10-100 \mu \mathrm{M} \\
10-100 \mu \mathrm{M} \\
10-100 \mu \mathrm{M} \\
10-100 \mu \mathrm{M} \\
100 \mathrm{mg} / \mathrm{kg}\end{array}$ & $\begin{array}{l}\text { In vitro } \\
\text { In vitro } \\
\text { In vitro } \\
\text { In vitro } \\
\text { In vivo }\end{array}$ & $\begin{array}{l}\text { Upregulate miR-384 and downregulate the PTN } \\
\text { expression level both in CRC cells and tissues }\end{array}$ & $\begin{array}{l}\text { Yao et al. } \\
(2019)\end{array}$ \\
\hline Genistein & $\begin{array}{l}\text { Puerariae lobatae } \\
\text { Radix }\end{array}$ & SW480 cells & $25-100 \mu \mathrm{M}$ & In vitro & $\begin{array}{l}\text { Increase the expression of TGF- } \beta 1 \text { and IncRNA } \\
\text { TTY18, followed by upregulated Ki- } 67 \text {, serum, and } \\
\text { SGK1 }\end{array}$ & $\begin{array}{l}\text { Chen et al. } \\
\text { (2020a) }\end{array}$ \\
\hline Baicalin & Scutellariae Radix & $\begin{array}{l}\text { RKO cells } \\
\text { HCT } 116 \text { cells } \\
\text { BALB/c mice }\end{array}$ & $\begin{array}{l}50,100 \mu \mathrm{g} / \mathrm{ml} \\
50,100 \mu \mathrm{g} / \mathrm{ml} \\
100,200 \mathrm{mg} / \mathrm{kg}\end{array}$ & $\begin{array}{l}\text { In vitro } \\
\text { In vitro } \\
\text { In vivo }\end{array}$ & $\begin{array}{l}\text { Inhibit cell growth, migration, and invasion and induce } \\
\text { cell apoptosis, induce cell cycle arrest in the G1 phase, } \\
\text { and suppress both endogenous and exogenous } \\
\text { TGF } \beta 1 \text {-induced EMT }\end{array}$ & $\begin{array}{l}\text { Yang et al. } \\
(2020)\end{array}$ \\
\hline Shikonin & Arnebiae Radix & $\begin{array}{l}\text { SW } 480 \text { cells } \\
\text { HCT } 116 \text { cells } \\
\text { BALB/c mice }\end{array}$ & $\begin{array}{l}2.5-15 \mu \mathrm{M} \\
2.5-15 \mu \mathrm{M} \\
3,6 \mathrm{mg} / \mathrm{kg}\end{array}$ & $\begin{array}{l}\text { In vitro } \\
\text { In vitro } \\
\text { In vivo }\end{array}$ & $\begin{array}{l}\text { Induce mitochondria-mediated apoptosis by } \mathrm{Bcl}-2 \\
\text { family protein and increase the intracellular ROS }\end{array}$ & $\begin{array}{l}\text { Liang et al. } \\
\text { (2017) }\end{array}$ \\
\hline Emodin & $\begin{array}{l}\text { Rhei Radix et } \\
\text { Rhizoma }\end{array}$ & $\begin{array}{l}\text { HCT } 116 \text { cells } \\
\text { BALB/c mice }\end{array}$ & $\begin{array}{l}15-60 \mu \mathrm{g} / \mathrm{ml} \\
20-80 \mathrm{mg} / \mathrm{kg}\end{array}$ & $\begin{array}{l}\text { In vitro } \\
\text { In vivo }\end{array}$ & $\begin{array}{l}\text { Block the growth and invasion of CRC cells by } \\
\text { restraining VEGFR2 }\end{array}$ & $\begin{array}{l}\text { Dai et al. } \\
\text { (2019a) }\end{array}$ \\
\hline Cordycepin & $\begin{array}{l}\text { Cordyceps } \\
\text { sinensis }\end{array}$ & HCT 116 cells & $62.5-540 \mu \mathrm{M}$ & In vitro & $\begin{array}{l}\text { Inhibit cell growth by the endogenous Bax-dependent } \\
\text { mitochondrial apoptosis pathway }\end{array}$ & $\begin{array}{l}\text { Li et al. } \\
(2019 b)\end{array}$ \\
\hline Paeoniflorin & $\begin{array}{l}\text { Paeonia lactiflora } \\
\text { Pall. }\end{array}$ & $\begin{array}{l}\text { HCT } 116 \text { cells } \\
\text { SW } 480 \text { cells } \\
\text { BALB/c mice }\end{array}$ & $\begin{array}{l}2.5-40 \mathrm{mM} \\
2.5-40 \mathrm{mM} \\
1 \mathrm{~g} / \mathrm{kg}\end{array}$ & $\begin{array}{l}\text { In vitro } \\
\text { In vitro } \\
\text { In vivo }\end{array}$ & $\begin{array}{l}\text { Inhibit migration and invasion and suppress cell } \\
\text { metastatic potential and decrease the expression of } \\
\text { HDAC2 and vimentin, increasing E-cadherin }\end{array}$ & $\begin{array}{l}\text { Zhang et al. } \\
\text { (2018) }\end{array}$ \\
\hline Ginsenoside Rh3 & $\begin{array}{l}\text { Ginseng Radix et } \\
\text { Rhizoma }\end{array}$ & $\begin{array}{l}\text { SW } 1116 \text { cells } \\
\text { BALB/c mice }\end{array}$ & $\begin{array}{l}60-240 \mu \mathrm{g} / \mathrm{ml} \\
100,200 \mathrm{mg} / \mathrm{kg}\end{array}$ & $\begin{array}{l}\text { In vitro } \\
\text { In vivo }\end{array}$ & $\begin{array}{l}\text { Inhibit proliferation and increase the ratio of apoptotic } \\
\text { cells, mRNA, and protein of caspase } 3\end{array}$ & $\begin{array}{l}\text { Cong et al. } \\
\text { (2020) }\end{array}$ \\
\hline Andrographolide & $\begin{array}{l}\text { Andrographis } \\
\text { Herba }\end{array}$ & HCT 116 cells & $5-100 \mu \mathrm{M}$ & In vitro & $\begin{array}{l}\text { Anti-TNF- } \alpha \text {-induced IL- } 8 \text { by inhibition of NADPH } \\
\text { oxidase/ROS/NF-kB and Src/MAPKs/AP-1 signaling } \\
\text { pathways }\end{array}$ & $\begin{array}{l}\text { Yuan et al. } \\
(2018)\end{array}$ \\
\hline
\end{tabular}


TABLE 4 | (Continued) Anti-CRC effect and mechanism of TCM compounds.

\begin{tabular}{|c|c|c|c|c|c|c|}
\hline Compound name & Main source & Cell lines/model & Dose & Detail & Mechanism & Ref \\
\hline Ursolic acid & $\begin{array}{l}\text { Ligustri lucidi } \\
\text { Fructus }\end{array}$ & $\begin{array}{l}\text { HCT } 116 \text { cells HCT } 8 \\
\text { cells }\end{array}$ & $\begin{array}{l}10-40 \mu \mathrm{M} \\
10-40 \mu \mathrm{M}\end{array}$ & $\begin{array}{l}\text { In vitro } \\
\text { In vitro }\end{array}$ & $\begin{array}{l}\text { Suppress the invasive by regulating the TGF- } \beta 1 / Z E B 1 / \\
\text { miR-200c signaling pathway }\end{array}$ & $\begin{array}{l}\text { Zhang et al. } \\
\text { (2019a) }\end{array}$ \\
\hline Celastrol & $\begin{array}{l}\text { Tripterygium } \\
\text { wilfordii }\end{array}$ & $\begin{array}{l}\text { HCT } 116 \text { cells } \\
\text { HT } 29 \text { cells }\end{array}$ & $\begin{array}{l}2.5-10 \mu \mathrm{M} \\
2.5-10 \mu \mathrm{M}\end{array}$ & $\begin{array}{l}\text { In vitro } \\
\text { In vitro }\end{array}$ & $\begin{array}{l}\text { Inhibit proliferation, migration, and NOS activity in the } \\
\text { cytoplasm and inhibit growth and migration }\end{array}$ & $\begin{array}{l}\text { Gao et al. } \\
(2019)\end{array}$ \\
\hline Bufalin & Bufonis venenum & $\begin{array}{l}\text { HCT } 116 \text { cells } \\
\text { LoVo cells } \\
\text { BALB/c mice }\end{array}$ & $\begin{array}{l}0.1-50 \mu \mathrm{M} \\
0.1-50 \mu \mathrm{M} \\
1 \mathrm{mg} / \mathrm{kg}\end{array}$ & $\begin{array}{l}\text { In vitro } \\
\text { In vitro } \\
\text { In vivo }\end{array}$ & $\begin{array}{l}\text { Reverse acquired drug resistance by inhibiting } \\
\text { stemness in colorectal cancer cells }\end{array}$ & $\begin{array}{l}\text { Sun et al. } \\
(2017)\end{array}$ \\
\hline Norcantharidin & $\begin{array}{l}\text { Mylabris phalerata } \\
\text { Pallas. }\end{array}$ & $\begin{array}{l}\text { HT } 29 \text { cells } \\
\text { LoVo cells SW } 620 \\
\text { cells }\end{array}$ & $\begin{array}{l}5,10 \mu \mathrm{g} / \mathrm{ml} \\
5,10 \mu \mathrm{g} / \mathrm{ml} \\
5,10 \mu \mathrm{g} / \mathrm{ml}\end{array}$ & $\begin{array}{l}\text { In vitro } \\
\text { In vitro } \\
\text { In vitro }\end{array}$ & $\begin{array}{l}\text { Cause proapoptotic and antiglycolytic effects through } \\
\text { modulation of Fam } 46 \mathrm{c} \text { expression and inhibition of } \\
\text { ERK1/2 signaling }\end{array}$ & $\begin{array}{l}\text { Zhang et al. } \\
\text { (2020b) }\end{array}$ \\
\hline Scutellarin & Erigerontis Herba & HCT 116 cells & $20-100 \mu \mathrm{M}$ & In vitro & $\begin{array}{l}\text { Reduce viability and induce apoptosis, reduce } \mathrm{Bcl}-2 \text {, } \\
\text { and increase Bax and phosphorylation of p53 }\end{array}$ & $\begin{array}{l}\text { Yang et al. } \\
(2017)\end{array}$ \\
\hline Paeonol & $\begin{array}{l}\text { Salvia } \\
\text { miltiorrhiza Bge. }\end{array}$ & НCT 116 cells & $\begin{array}{l}7.8125-500 \mu \mathrm{g} / \\
\mathrm{ml}\end{array}$ & In vitro & $\begin{array}{l}\text { Induce } G_{0} / G_{1} \text { phase arrest and cell apoptosis by } \\
\text { inhibiting the Wnt/ } \beta \text {-catenin signaling pathway }\end{array}$ & $\begin{array}{l}\text { Liu et al. } \\
\text { (2020b) }\end{array}$ \\
\hline
\end{tabular}

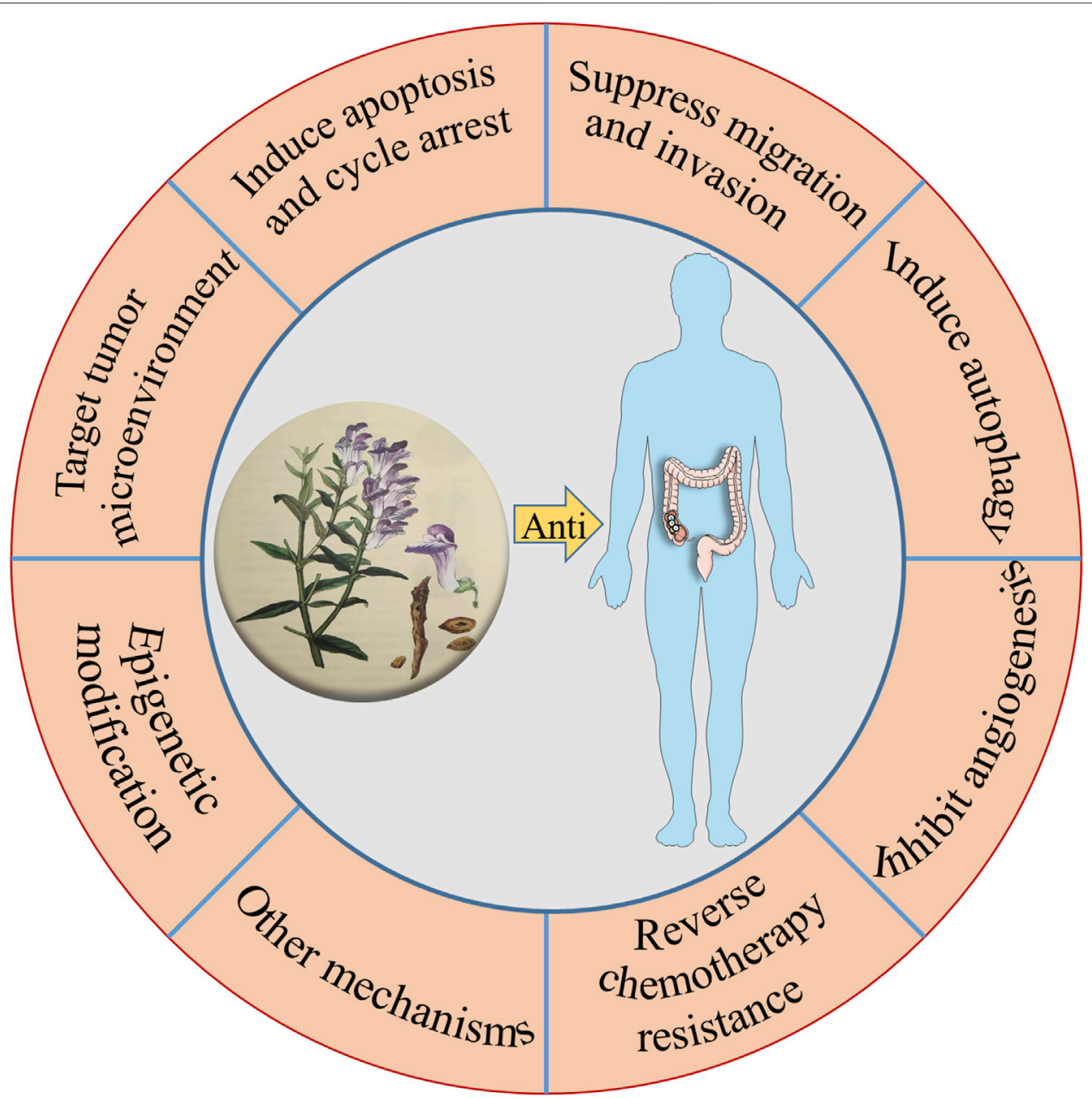

FIGURE 2 | The main mechanisms of TCM for the treatment of CRC.

effective agent for the treatment of CRC, which has attentiongrabbing clinical application and research value. Although there is increasing research on this active ingredient in the treatment of
CRC, the mechanisms of shikonin against CRC are still not fully clear. More detailed information concerning anti-CRC of TCM compounds is depicted in Table 4. 
To sum up, the compounds in TCM have shown great potential in anti-CRC. In terms of mechanism, as can be seen throughout this review, it is easy to realize that these anti-CRC activities mentioned above are related to the inhibition on the proliferation, migration, induction of apoptosis, and autophagy (Chen et al., 2021), as well as the target of the tumor microenvironment (Figure 2). The research studies on the anti-CRC effects of TCM listed above are only some instances. Consequently, this is a wide-open field for additional investigation, with other novel components in TCM possessing anti-CRC activity needed to be explored. In the future, these Chinese herbal medicinal ingredients and biochemical agents may orchestrate the anti-CRC effects in clinical practice.

\section{DISCUSSION AND PERSPECTIVES}

With a unique philosophy and clinical treatment principles, TCM strictly relies on the two vital therapeutic methods of holism and syndrome differentiation. A rich clinical experience has accumulated in the treatment of multiple diseases. Although some reports, including clinical trials, have demonstrated that TCM formulations have advantages against multiple targets in the treatment of multiple diseases, it still has some limitations. First of all, TCM is rich in a considerable number of chemical components, and each component produces a variety of biological effects through interaction. Therefore, it is difficult to clarify the relatively clear material basis, target, and molecular biological mechanism. Moreover, it is worthy of further explanation whether the numerous targets of TCM ingredients also mediate its adverse reactions. Second, increasing studies showed that most of the components in TCM, such as alkaloids, flavonoids, and saponins, have some defects, such as low solubility, needy bioavailability, and poor stability, which undoubtedly limited the further application and promotion of TCM products to some extent. In addition, the current research of TCM mainly focuses on one or several single components, which is divorced from the guidance of TCM theory. Whether these single active ingredients can replace the effective material basis of the whole TCM is worth thinking deeply. Besides, TCM is also faced with the problems of pharmacokinetic/pharmacodynamic (PK/PD) uncorrelation in the evaluation of drug formation. Consequently, it is urgent to excavate more technologies and means for the discovery of TCM.

\section{Excavating the Effective Material Basis of Anti-Colorectal-Cancer Traditional Chinese Medicine Based on Multiple Types of Target Omics Analysis}

The effective substance of TCM refers to the chemical composition (group) in TCM or CMF, which can intuitively express the clinical efficacy of pharmaceutical ingredients. Currently, although there are extensive works on the anti-CRC effect of TCM, the effective substance remains elusive. In addition, TCM possesses the characteristics of multicomponent, multitarget, and synergistic effects with a relatively complex metabolic process in vivo. Also, the phenomenon of synergy or inhibition between components in the process of absorption and metabolism frequently occurs. In recent years, owing to the development of novel technologies, a series of multitypes of omics analysis, such as transcriptomics, metabolomics, and proteomics, have entered the field of the discovery of effective substances of TCM one after another, which will contribute to the lucidity of the material basis of TCM in anti-CRC. In the future, we can systematically characterize the efficacy material base of TCM against CRC through multiomics analysis and comprehensively elaborate the procedure of ingredient intervention in cancer employing genomics, metabolomics, proteomics, and bioinformatics, so as to more systematically explicate the connotation of the material basis of TCM against CRC. These research studies are capable of resolving the decipher relationship of "Prescription-Disease-Syndrome" to a certain extent and organically combining "molecular identification of disease and syndrome-pharmacodynamic material basis-key molecular mechanism verification" to assist the development of "precision medicine" of TCM against CRC.

\section{Guiding the Development and Application of Anti-Colorectal-Cancer Traditional Chinese Medicine by Reverse Pharmacology}

The development of modern chemical agents mostly adopts the research procedure of "Bench (preclinical study)-to-Bedside (clinical practice)." However, the vast majority of TCM has entered clinical practice under the guidance of TCM theory without undergoing the "Bench." It means that TCM or medicine material crude slices can render the patients directly through the pharmacy management channel or pharmacy of the hospital without relevant pharmacological studies. Although TCM practitioners own affluent experience in this approach of medication, preclinical studies such as pharmacodynamics, pharmacokinetics, and toxicology ought not to be ignored. Hence, there is a gap with regard to its safety and effectiveness, namely, sufficient and credible preclinical evidences and systematic randomized clinical trials. Taking the clinical TCM for the treatment of CRC as an example, although this ancient theory claims that TCM has a positive effect in the treatment of this malignant tumor, the pharmacokinetic parameters, potential targeting mechanism, and toxicological information of different components in it have not been entirely expounded. Therefore, we must unearth more preclinical research data to guide the clinical application of anti-CRC TCM. In a sense, this is the process of reverse pharmacology guiding the development and application of anti-CRC Chinese medicine (Figure 3).

\section{Scientific and Reasonable Nanostrategy to Make Up for the Deficiency of Clinical Transformation of Anti-Colorectal-Cancer Traditional Chinese Medicine}

The active ingredients of anti-CRC on the market or in the development stage currently mostly originate from natural 

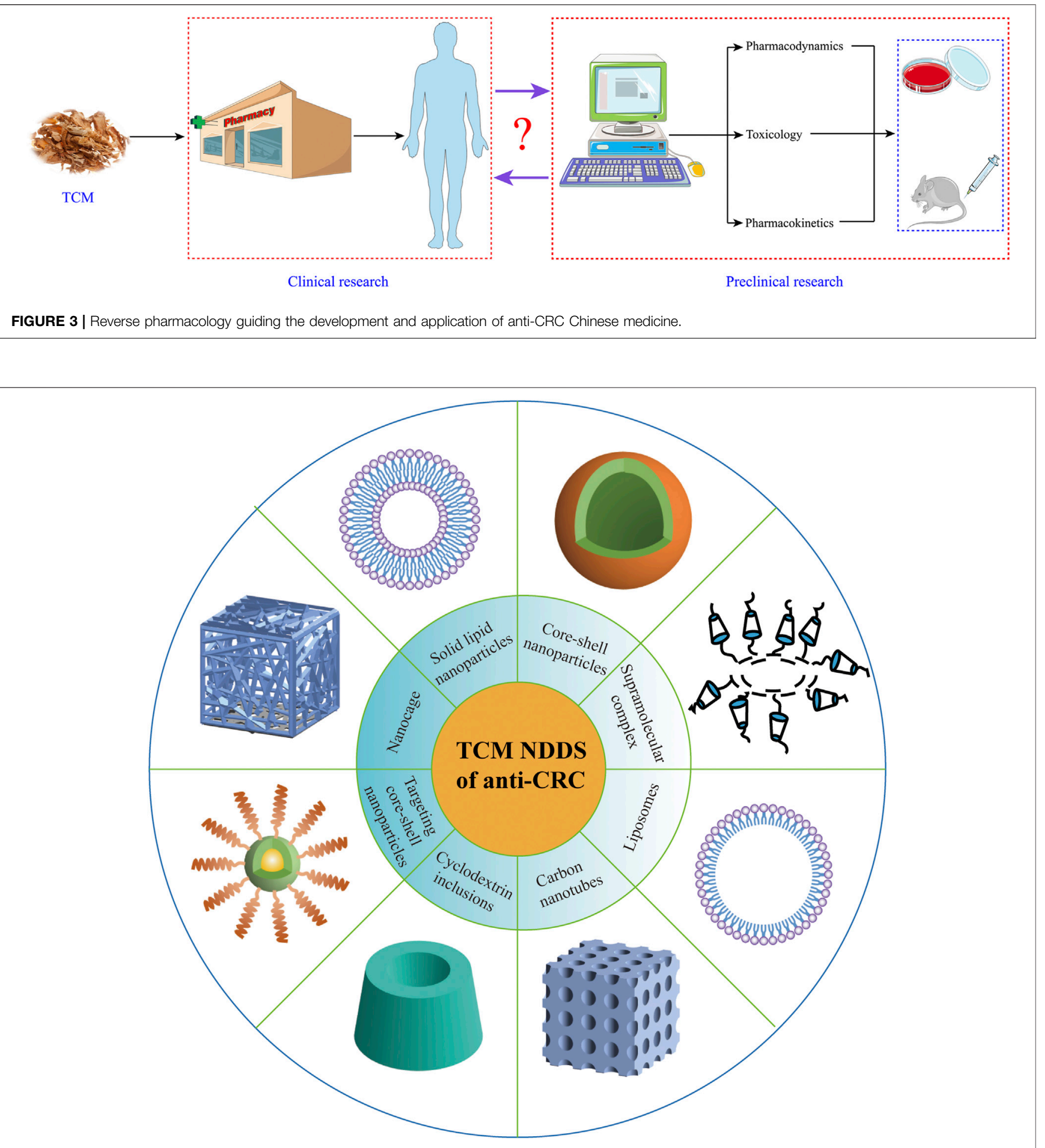

FIGURE 4 | Nanodelivery system of TCM for the treatment of CRC.

Chinese herbal medicines, which have promising antitumor effects and less toxic and side effects, as well as enhancement of human immunity. Nevertheless, most of the antitumor active ingredients of Chinese herbal medicine show some issues, such as poor aqueous solubility (Rafiee et al., 2019), needy bioavailability (Ban et al., 2020), and awful specific distribution (Huo et al., 2020). In recent years, although the applications of nanotechnologies such as liposome, nanoparticles, polymer 
micelles, microemulsion, and the biomimetic drug delivery system have eliminated the abovementioned flaws of active ingredients in TCM, there are still some problems that do exist. For example, Japanese researchers applied albumin combined with paclitaxel nanoparticles to carry out a phase III clinical study on 741 patients with advanced gastric cancer who were not sensitive to first-line chemotherapy. The results demonstrated that the median survival time of patients treated with nano-paclitaxel was only slightly better than that of patients treated with conventional paclitaxel (Shitara et al., 2017). In addition, a project of 1,206 patients with early breast cancer also showed that although albumin combined with paclitaxel nanoparticles performed significantly better than conventional paclitaxel preparations in inhibiting tumor metastasis, there was no significant difference in long-term survival between the two treatment groups (Untch et al., 2019). These studies suggest that in vitro cell models and in vivo animal models often do not truly reflect the pathophysiological process of the human body, which may also be because the research on the correlation between them relatively remains scarce. Besides, it is well known that the effective components of TCM against CRC own the effect on multitarget. Like that, does this seemingly advantageous feature also result in the situation that the targeting effect of TCM components too scattered? Therefore, although the effective components of TCM against CRC can be nanomodified, it is essential to establish a scientific, reasonable, and systematic evaluation system (Figure 4). Also importantly, future works may reap huge fruits from having components of TCM against the CRC structure modified, and this will be conducive to formulate corresponding strategies to overcome the shortage of clinical transformation of anti-CRC agents.

\section{Detecting the Anti-Colorectal-Cancer Mechanism of Effective Components of Traditional Chinese Medicine Based on the Whole Effect Mediated by Gut Microbiota}

The study of drug metabolism in vivo has always been a paramount link in the field of pharmacy and the development of novel agents, as the favorable oral absorption properties and excellent bioavailability are the current international indicators to evaluate the drug properties. In recent years, the efficacy of several active ingredients of TCM against CRC has been confirmed in clinical practice. However, there is a special phenomenon in the field of TCM that should be taken into account. A considerable number of active ingredients exert therapeutic effects or even intense influence, but with a low exposure in the blood. Most of these components stem from natural products with various structures (such as alkaloids, flavonoids, terpenoids, and saponins), which generally possess the characteristics of a definite curative effect, but unfavorable intestinal absorption and unsatisfactory oral bioavailability. Therefore, these characteristics give rise to the re-exploration of the existing concept of drug bioavailability, namely, whether the drug molecule itself as the only indicator of bioavailability is correct or not. Lately, gut microbiota as the "Forgotten and Invisible Organ" of the human body has been extensively concerned. The latest research harbored the idea that the gut microbiota is closely related to the occurrence and development of CRC (Vivarelli et al., 2019; Song et al., 2020). For the metabolism or transformation of active ingredients in oral Chinese medicine, gut microbiota is still an unknown territory, as the type and quantity of biochemical enzymes in the intestinal cavity may be more than those in other organs in the body; thus, the products or degradation fragments produced after metabolism may be more complicated (Zhao et al., 2021). Thus, it is of great significance to probe the gut microbiota for the metabolism or transformation of oral insoluble TCM (Feng et al., 2019a; Sun et al., 2020a). Berberine can stimulate intestinal microorganisms to produce metabolites with rosy safety and biological activity, such as shortchain fatty acids (SCFAs). When studying the anti-CRC effect of natural ingredients, we should take the prototype agents and the endogenous metabolites produced by gut microbiota as a whole based on the interaction between drugs and gut microbiota to expound the pharmacokinetics and pharmacodynamic mechanism in vivo, which may also be a valuable implication for the treatment of chronic tumors including CRC in the future.

\section{CONCLUSION}

Over the past few decades, the incidence rate of CRC in most countries or regions of the world has been remarkably increased, which undoubtedly increases the health burden of various countries on the treatment of this malignant malady. The existing chemotherapy approaches for CRC possess evident adverse reactions and dreadful complications; thus, it is urgent to develop novel specific drugs to curb this unfavorable situation. Owing to the increasing R\&D time and cost of chemosynthetic agents, the majority of the pharmaceutical developers pay increasing attention to unearthing novel and efficient natural ingredients and their derivatives from TCM for the treatment of CRC. However, due to the existence of adverse factors such as the difference of administration methods and the complexity of clinical trial conditions, the efficacy and mechanism of the most effective components of TCM in the treatment of CRC are inconclusive. Therefore, there is an urgent need for large-scale multicenter randomized controlled trials for TCM against CRC.

In view of that animal models often do not truly reflect the pathophysiological process of the human body, there is still a long way to go for nanodrugs to be popularized/transformed from animal-level simulation to human clinical application, where the effectiveness of nanodrugs in vivo has been queried. Of course, it is more convincing that the effectiveness of nanodrugs can be proved in the human body, but the current conditions are arduous to achieve. In order to better evaluate the process and antitumor effect, models more similar to the human physiological environment need to be further explored. At present, the tumorbearing mouse model relatively truly reflects the physiological environment of the human body to a certain extent. Although this is not the best evaluation method, it is also adequate to expound the problem, which also lays a solid foundation for human experiments in the future. In addition, strengthening the correlation between the preclinical research model and the fate 
of nanocarriers in the human body will also contribute to overcome this limitation.

Clinical trials require to be initiated to more accurately test and verify whether TCM is effective in the treatment of CRC. In order to accelerate the clinical transformation of TCM products, numerous factors need to be taken into account, such as the drug dose variance, interindividual patient variability, and differences between animal models and patients, which make the design of clinical trials full of challenges. In addition, at present, the research of TCM on CRC mostly dwells in the molecular level. With the emergence of novel technologies such as whole-genome sequencing, genome editing, and quantitative proteomics analysis, we can have a more thorough and accurate understanding of the molecular targets and signal pathways regarding its anti-CRC effect. As investigation into this field continues, hopefully, the intervention of anti-CRC TCM can be combined with other therapies currently being developed, to apply these ancient herbal medicines in a more safe and reasonable way based on conclusive evidence.

\section{REFERENCES}

Almeida, A. F., Borge, G. I. A., Piskula, M., Tudose, A., Tudoreanu, L., Valentová, K., et al. (2018). Bioavailability of Quercetin in Humans with a Focus on Interindividual Variation. Compr. Rev. Food Sci. Food Saf. 17, 714-731. doi:10.1111/1541-4337.12342

Andújar, I., Martí-Rodrigo, A., Giner, R., Ríos, J., and Recio, M. (2018). Shikonin Prevents Early Phase Inflammation Associated with Azoxymethane/Dextran Sulfate Sodium-Induced Colon Cancer and Induces Apoptosis in Human Colon Cancer Cells. Planta Med. 84, 674-683. doi:10.1055/a-0599-1145

Auyeung, K. K. W., Law, P. C., and Ko, J. K. S. (2014). Combined Therapeutic Effects of Vinblastine and Astragalus Saponins in Human colon Cancer Cells and Tumor Xenograft via Inhibition of Tumor Growth and Proangiogenic Factors. Nutr. Cancer 66, 662-674. doi:10.1080/01635581.2014.894093

Ban, E., An, S. H., Park, B., Park, M., Yoon, N.-E., Jung, B. H., et al. (2020). Improved Solubility and Oral Absorption of Emodin-Nicotinamide Cocrystal over Emodin with PVP as a Solubility Enhancer and Crystallization Inhibitor. J. Pharm. Sci. 109, 3660-3667. doi:10.1016/j.xphs.2020.09.030

Bao, C., Liu, T., Qian, L., Xiao, C., Zhou, X., Ai, H., et al. (2021). Shikonin Inhibits Migration and Invasion of Triple-Negative Breast Cancer Cells by Suppressing Epithelial-Mesenchymal Transition via miR-17-5p/PTEN/Akt Pathway. J. Cancer 12, 76-88. doi:10.7150/jca.47553

Botteri, E., Iodice, S., Bagnardi, V., Raimondi, S., Lowenfels, A. B., and Maisonneuve, P. (2008). Smoking and Colorectal Cancer. JAMA 300, 2765-2778. doi:10.1001/ jama.2008.839

Bray, F., Ferlay, J., Soerjomataram, I., Siegel, R. L., Torre, L. A., and Jemal, A. (2018). Global Cancer Statistics 2018: GLOBOCAN Estimates of Incidence and Mortality Worldwide for 36 Cancers in 185 Countries. CA: A Cancer J. Clinicians 68, 394-424. doi:10.3322/caac.21492

Bu, L., Dai, O., Zhou, F., Liu, F., Chen, J.-F., Peng, C., et al. (2020). Traditional Chinese Medicine Formulas, Extracts, and Compounds Promote Angiogenesis. Biomed. Pharmacother. 132, 110855. doi:10.1016/j.biopha.2020.110855

Buhrmann, C., Shayan, P., Brockmueller, A., and Shakibaei, M. (2020). Resveratrol Suppresses Cross-Talk between Colorectal Cancer Cells and Stromal Cells in Multicellular Tumor Microenvironment: A Bridge between In Vitro and In Vivo Tumor Microenvironment Study. Molecules 25, 4292. doi:10.3390/ molecules25184292

Buhrmann, C., Shayan, P., Goel, A., and Shakibaei, M. (2017). Resveratrol Regulates Colorectal Cancer Cell Invasion by Modulation of Focal Adhesion Molecules. Nutrients 9, 1073. doi:10.3390/nu9101073

Buhrmann, C., Yazdi, M., Popper, B., Shayan, P., Goel, A., Aggarwal, B. B., et al. (2019). Evidence that TNF- $\beta$ Induces Proliferation in Colorectal Cancer Cells and Resveratrol Can Down-Modulate it. Exp. Biol. Med. (Maywood) 244, 1-12. doi:10.1177/1535370218824538

\section{AUTHOR CONTRIBUTIONS}

QS and HX contributed to the conception and design of the study; QS, MH, and MZ prepared the original draft; HZ, LC, SZ, ML, HY, and SR reviewed and edited the manuscript; and HX supervised the study.

\section{FUNDING}

This work was sponsored by the National Natural Science Foundation of China (Nos. 81573813 and 81173598), the Excellent Talent Program of Chengdu University of Traditional Chinese Medicine (Nos. YXRC2019002 and ZRYY 1917), Sichuan Provincial Administration of Traditional Chinese Medicine of China (No. 2021MS447), and the Open Research Fund of State Key Laboratory of Southwestern Chinese Medicine Resources (No. 2020XSGG006).

Cai, Q., Lin, J., Wei, L., Zhang, L., Wang, L., Zhan, Y., et al. (2012). Hedyotis Diffusa Willd Inhibits Colorectal Cancer Growth In Vivo via Inhibition of STAT3 Signaling Pathway. Int. J. Mol. Sci. 13, 6117-6128. doi:10.3390/ ijms13056117

Chamseddine, A. N., Ducreux, M., Armand, J.-P., Paoletti, X., Satar, T., Paci, A., et al. (2019). Intestinal Bacterial $\beta$-glucuronidase as a Possible Predictive Biomarker of Irinotecan-Induced Diarrhea Severity. Pharmacol. Ther. 199, 1-15. doi:10.1016/j.pharmthera.2019.03.002

Chan, Y.-T., Cheung, F., Zhang, C., Fu, B., Tan, H.-Y., Norimoto, H., et al. (2020). Ancient Chinese Medicine Herbal Formula Huanglian Jiedu Decoction as a Neoadjuvant Treatment of Chemotherapy by Improving Diarrhea and Tumor Response. Front. Pharmacol. 11, 252. doi:10.3389/fphar.2020.00252

Chen, C., Yao, X., Xu, Y., Zhang, Q., Wang, H., Zhao, L., et al. (2019). Dahuang Zhechong Pill Suppresses Colorectal Cancer Liver Metastasis via Ameliorating Exosomal CCL2 Primed Pre-metastatic Niche. J. Ethnopharmacology 238, 111878. doi:10.1016/j.jep.2019.111878

Chen, G., Yang, Y., Hu, C., Cheng, X., Xu, Y., Cai, X., et al. (2016). Protective Effects of Huangqin Decoction against Ulcerative Colitis and Associated Cancer in Mice. Oncotarget 7, 61643-61655. doi:10.18632/oncotarget.11426

Chen, S., and Shen, X. (2020). Long Noncoding RNAs: Functions and Mechanisms in colon Cancer. Mol. Cancer 19, 167. doi:10.1186/s12943-020-01287-2

Chen, X., Wu, Y., Gu, J., Liang, P., Shen, M., Xi, J., et al. (2020). Anti-invasive Effect and Pharmacological Mechanism of Genistein against Colorectal Cancer. Biofactors 46, 620-628. doi:10.1002/biof.1627

Chen, Y.-X., Gao, Q.-Y., Zou, T.-H., Wang, B.-M., Liu, S.-D., Sheng, J.-Q., et al. (2020b). Berberine versus Placebo for the Prevention of Recurrence of Colorectal Adenoma: a Multicentre, Double-Blinded, Randomised Controlled Study. Lancet Gastroenterol. Hepatol. 5, 267-275. doi:10.1016/ s2468-1253(19)30409-1

Chen, Y., Gao, Y., Yi, X., Zhang, J., Chen, Z., and Wu, Y. (2020). Integration of Transcriptomics and Metabolomics Reveals the Antitumor Mechanism Underlying Shikonin in Colon Cancer. Front. Pharmacol. 11, 544647. doi:10.3389/fphar.2020.544647

Chen, Y., Ni, J., Gao, Y., Zhang, J., Liu, X., Chen, Y., et al. (2020). Integrated Proteomics and Metabolomics Reveals the Comprehensive Characterization of Antitumor Mechanism Underlying Shikonin on colon Cancer PatientDerived Xenograft Model. Sci. Rep. 10, 14092. doi:10.1038/s41598-02071116-5

Chen, L., He, M., Zhang, M., Sun, Q., Zeng, S., Zhao, H., et al. (2021). The Role of Non-coding RNAs in Colorectal Cancer, with a Focus on its Autophagy. Pharmacol. Ther. 226, 107868. doi:10.1016/j.pharmthera.2021.107868

Cheng, K.-W., Tseng, C.-H., Tzeng, C.-C., Leu, Y.-L., Cheng, T.-C., Wang, J.-Y., et al. (2019). Pharmacological Inhibition of Bacterial $\beta$-glucuronidase Prevents Irinotecan-Induced Diarrhea without Impairing its Antitumor Efficacy In Vivo. Pharmacol. Res. 139, 41-49. doi:10.1016/j.phrs.2018.10.029 
Chien, J.-H., Lee, S.-C., Chang, K.-F., Huang, X.-F., Chen, Y.-T., and Tsai, N.-M. (2020). Extract of Pogostemon Cablin Possesses Potent Anticancer Activity against Colorectal Cancer Cells In Vitro and In Vivo. Evidence-Based Complement. Altern. Med. 2020, 1-11. doi:10.1155/2020/9758156

Chu, L., Zhao, H., Fang, J., Li, C., Liu, Z., Cui, R., et al. (2015). The Traditional Chinese Medicinal Formula BDL301 Suppresses Tumor Growth by Inhibiting STAT3 Pathway and Inducing Apoptosis in Colorectal Cancer Cells. DNA Cel Biol. 34, 178-188. doi:10.1089/dna.2014.2532

Cong, Z., Zhao, Q., Yang, B., Cong, D., Zhou, Y., Lei, X., et al. (2020). Ginsenoside Rh3 Inhibits Proliferation and Induces Apoptosis of Colorectal Cancer Cells. Pharmacology 105, 329-338. doi:10.1159/000503821

Dai, G., Ding, K., Cao, Q., Xu, T., He, F., Liu, S., et al. (2019a). Emodin Suppresses Growth and Invasion of Colorectal Cancer Cells by Inhibiting VEGFR2. Eur. J. Pharmacol. 859, 172525. doi:10.1016/j.ejphar.2019.172525

Dai, W., Mu, L., Cui, Y., Li, Y., Chen, P., Xie, H., et al. (2019b). Berberine Promotes Apoptosis of Colorectal Cancer via Regulation of the Long Non-coding RNA (lncRNA) Cancer Susceptibility Candidate 2 (CASC2)/AU-Binding Factor 1 (AUF1)/B-Cell CLL/Lymphoma 2 (Bcl-2) Axis. Med. Sci. Monit. 25, 730-738. doi:10.12659/MSM.912082

Dai, W., Mu, L., Cui, Y., Li, Y., Chen, P., Xie, H., et al. (2019c). Long Non-coding RNA CASC2 E-nhances B-erberine-induced C-ytotoxicity in C-olorectal C-ancer C-ells by S-ilencing BCL2. Mol. Med. Rep. 20, 995-1006. doi:10.3892/mmr.2019.10326

Darband, S. G., Kaviani, M., Yousefi, B., Sadighparvar, S., Pakdel, F. G., Attari, J. A., et al. (2018). Quercetin: A Functional Dietary Flavonoid with Potential ChemoPreventive Properties in Colorectal Cancer. J. Cel Physiol 233, 6544-6560. doi:10.1002/jcp.26595

Darband, S. G., Sadighparvar, S., Yousefi, B., Kaviani, M., Ghaderi-Pakdel, F., Mihanfar, A., et al. (2020). Quercetin Attenuated Oxidative DNA Damage through NRF2 Signaling Pathway in Rats with DMH Induced colon Carcinogenesis. Life Sci. 253, 117584. doi:10.1016/j.lfs.2020.117584

Dariya, B., Behera, S. K., Srivani, G., Aliya, S., Alam, A., and Nagaraju, G. P. (2020). Resveratrol Binds and Activates RKIP Protein in Colorectal Cancer. Amino Acids 52, 1299-1306. doi:10.1007/s00726-020-02889-2

De Santis, S., Kunde, D., Serino, G., Galleggiante, V., Caruso, M. L., Mastronardi, M., et al. (2016). Secretory Leukoprotease Inhibitor Is Required for Efficient Quercetin-Mediated Suppression of TNFa Secretion. Oncotarget 7, 75800-75809. doi:10.18632/oncotarget.12415

Dekker, E., Tanis, P. J., Vleugels, J. L. A., Kasi, P. M., and Wallace, M. B. (2019). Colorectal Cancer. The Lancet 394, 1467-1480. doi:10.1016/s0140-6736(19) 32319-0

Deng, S., Hu, B., An, H.-M., Du, Q., Xu, L., Shen, K.-P., et al. (2013a). Teng-LongBu-Zhong-Tang, a Chinese Herbal Formula, Enhances Anticancer Effects of 5 Fluorouracil in CT26 colon Carcinoma. BMC Complement. Altern. Med. 13, 128. doi:10.1186/1472-6882-13-128

Deng, S., Tang, Q., Duan, X., Fan, H., Zhang, L., Zhu, X., et al. (2019). Uncovering the Anticancer Mechanism of Compound Sophorae Decoction against Ulcerative Colitis-Related Colorectal Cancer in Mice. Evidence-Based Complement. Altern. Med. 2019, 1-16. doi:10.1155/2019/8128170

Deng, W., Sui, H., Wang, Q., He, N., Duan, C., Han, L., et al. (2013b). A Chinese Herbal Formula, Yi-Qi-Fu-Sheng, Inhibits Migration/invasion of Colorectal Cancer by Down-Regulating MMP-2/9 via Inhibiting the Activation of ERK/ MAPK Signaling Pathways. BMC Complement. Altern. Med. 13, 65. doi:10.1186/1472-6882-13-65

Dong, B., Yang, Z., Ju, Q., Zhu, S., Wang, Y., Zou, H., et al. (2020). Anticancer Effects of Fufang Yiliu Yin Formula on Colorectal Cancer through Modulation of the PI3K/Akt Pathway and BCL-2 Family Proteins. Front. Cel Dev. Biol. 8, 704. doi:10.3389/fcell.2020.00704

Dong, J., Lu, L., Le, J., Yan, C., Zhang, H., and Li, L. (2018). Philosophical Thinking of Chinese Traditional Medicine. Tradit. Med. Mod. Med. 01, 1-10. doi:10.1142/s2575900018100018

Fan, Y., Jin, S., He, J., Shao, Z., Yan, J., Feng, T., et al. (2012). Effect of $\beta, \beta$-Dimethylacrylshikonin on Inhibition of Human Colorectal Cancer Cell Growth In Vitro and In Vivo. Int. J. Mol. Sci. 13, 9184-9193. doi:10.3390/ ijms13079184

Fan, Y., Ma, Z., Zhao, L., Wang, W., Gao, M., Jia, X., et al. (2020). Anti-tumor Activities and Mechanisms of Traditional Chinese Medicines Formulas: A Review. Biomed. Pharmacother. 132, 110820. doi:10.1016/j.biopha.2020.110820
Feng, W., Ao, H., Peng, C., and Yan, D. (2019a). Gut Microbiota, a New Frontier to Understand Traditional Chinese Medicines. Pharmacol. Res. 142, 176-191. doi:10.1016/j.phrs.2019.02.024

Feng, X., Sureda, A., Jafari, S., Memariani, Z., Tewari, D., Annunziata, G., et al. (2019b). Berberine in Cardiovascular and Metabolic Diseases: From Mechanisms to Therapeutics. Theranostics 9, 1923-1951. doi:10.7150/ thno.30787

Gao, Y., Zhou, S., Pang, L., Yang, J., Li, H. J., Huo, X., et al. (2019). Celastrol Suppresses Nitric Oxide Synthases and the Angiogenesis Pathway in Colorectal Cancer. Free Radic. Res. 53, 324-334. doi:10.1080/10715762.2019.1575512

Gavrilas, L. I., Cruceriu, D., Ionescu, C., Miere, D., and Balacescu, O. (2019). Proapoptotic Genes as New Targets for Single and Combinatorial Treatments with Resveratrol and Curcumin in Colorectal Cancer. Food Funct. 10, 3717-3726. doi:10.1039/c9fo01014a

Ge, Y., Gao, Q., Yan, F., Zhang, X., Liu, Y., and Zhou, Y. (2019). Su Yang Decoction Induces Human colon Carcinoma Cell Apoptosis by Activating Caspases. Oncol. Lett. 17, 422-431. doi:10.3892/ol.2018.9625

Gong, B., Kao, Y., Zhang, C., Zhao, H., Sun, F., and Gong, Z. (2019). Exploring the Pharmacological Mechanism of the Herb Pair "HuangLian-GanJiang" against Colorectal Cancer Based on Network Pharmacology. Evidence-Based Complement. Altern. Med. 2019, 1-12. doi:10.1155/2019/2735050

Gong, C., Hu, X., Xu, Y., Yang, J., Zong, L., Wang, C., et al. (2020). Berberine Inhibits Proliferation and Migration of Colorectal Cancer Cells by Downregulation of GRP78. Anticancer Drugs 31, 141-149. doi:10.1097/ CAD.0000000000000835

Guo, C., He, J., Song, X., Tan, L., Wang, M., Jiang, P., et al. (2019). Pharmacological Properties and Derivatives of Shikonin-A Review in Recent Years. Pharmacol. Res. 149, 104463. doi:10.1016/j.phrs.2019.104463

Gupta, M. K., Vadde, R., and Sarojamma, V. (2020). Curcumin - A Novel Therapeutic Agent in the Prevention of Colorectal Cancer. Curr. Drug. Metab. 20, 977-987. doi:10.2174/1389200220666191007153238

Hallajzadeh, J., Maleki Dana, P., Mobini, M., Asemi, Z., Mansournia, M. A., Sharifi, M., et al. (2020). Targeting of Oncogenic Signaling Pathways by Berberine for Treatment of Colorectal Cancer. Med. Oncol. 37, 49. doi:10.1007/s12032-020-01367-9

Han, B., Jiang, P., Li, Z., Yu, Y., Huang, T., Ye, X., et al. (2018). Coptisine-induced Apoptosis in Human colon Cancer Cells (HCT-116) Is Mediated by PI3K/Akt and Mitochondrial-Associated Apoptotic Pathway. Phytomedicine 48, 152-160. doi:10.1016/j.phymed.2017.12.027

Han, W., Yin, H., Ma, H., Wang, Y., Kong, D., and Fan, Z. (2020). Curcumin Regulates ERCC1 Expression and Enhances Oxaliplatin Sensitivity in Resistant Colorectal Cancer Cells through its Effects on miR-409-3p. Evidence-Based Complement. Altern. Med. 2020, 1-16. doi:10.1155/2020/8394574

Han, Y., Wang, H., Xu, W., Cao, B., Han, L., Jia, L., et al. (2016). Chinese Herbal Medicine as Maintenance Therapy for Improving the Quality of Life for Advanced Non-small Cell Lung Cancer Patients. Complement. Therapies Med. 24, 81-89. doi:10.1016/j.ctim.2015.12.008

Hattori, T., Imaoka, A., Akiyoshi, T., and Ohtani, H. (2019). Irinotecan-induced Gastrointestinal Damage Impairs the Absorption of Dabigatran Etexilate. Biopharm. Drug Dispos 40, 315-324. doi:10.1002/bdd.2205

Hesari, A., Azizian, M., Sheikhi, A., Nesaei, A., Sanaei, S., Mahinparvar, N., et al. (2019). Chemopreventive and Therapeutic Potential of Curcumin in Esophageal Cancer: Current and Future Status. Int. J. Cancer 144, 1215-1226. doi:10.1002/ijc.31947

Hong, X.-C., Liang, Q.-L., Luo, X.-B., Hu, K.-H., Yang, H.-X., Ou, W.-t., et al. (2020). Clinical Study of XiangShaLiuJunZi Decoction Combined with S-1 as Maintenance Therapy for Stage III or IV Gastric Carcinoma and Colorectal Carcinoma. Medicine 99, e20081. doi:10.1097/MD.0000000000020081

Hou, F., Li, W., Shi, Q., Li, H., Liu, S., Zong, S., et al. (2016). Yi Ai Fang, a Traditional Chinese Herbal Formula, Impacts the Vasculogenic Mimicry Formation of Human Colorectal Cancer through HIF-1 $\alpha$ and Epithelial Mesenchymal Transition. BMC Complement. Altern. Med. 16, 428. doi:10.1186/s12906-016-1419-Z

Huang, H., Liao, D., Dong, Y., and Pu, R. (2020a). Effect of Quercetin Supplementation on Plasma Lipid Profiles, Blood Pressure, and Glucose Levels: a Systematic Review and Meta-Analysis. Nutr. Rev. 78, 615-626. doi:10.1093/nutrit/nuz071

Huang, J., Chen, Z.-H., Ren, C.-M., Wang, D.-X., Yuan, S.-X., Wu, Q.-X., et al. (2015). Antiproliferation Effect of Evodiamine in Human colon Cancer Cells Is 
Associated with IGF-1/HIF-1a Downregulation. Oncol. Rep. 34, 3203-3211. doi:10.3892/or.2015.4309

Huang, L., Zhang, S., Zhou, J., and Li, X. (2019). Effect of Resveratrol on Drug Resistance in colon Cancer Chemotherapy. RSC Adv. 9, 2572-2580. doi:10.1039/c8ra08364a

Huang, S., Zhang, Z., Li, W., Kong, F., Yi, P., Huang, J., et al. (2020b). Network Pharmacology-Based Prediction and Verification of the Active Ingredients and Potential Targets of Zuojinwan for Treating Colorectal Cancer. Drug. Des. Devel. Ther. Vol. 14, 2725-2740. doi:10.2147/DDDT.S250991

Huo, M., Wang, H., Zhang, Y., Cai, H., Zhang, P., Li, L., et al. (2020). Co-delivery of Silybin and Paclitaxel by Dextran-Based Nanoparticles for Effective Anti-tumor Treatment through Chemotherapy Sensitization and Microenvironment Modulation. J. Controlled Release 321, 198-210. doi:10.1016/ j.jconrel.2020.02.017

Jakopovic, B., Oršolić, N., and Kraljević Pavelić, S. (2020). Antitumor, Immunomodulatory and Antiangiogenic Efficacy of Medicinal Mushroom Extract Mixtures in Advanced Colorectal Cancer Animal Model. Molecules 25, 5005. doi:10.3390/molecules25215005

Jiang, F., Liu, M., Wang, H., Shi, G., Chen, B., Chen, T., et al. (2020). Wu Mei Wan Attenuates CAC by Regulating Gut Microbiota and the NF-kB/IL6-STAT3 Signaling Pathway. Biomed. Pharmacother. 125, 109982. doi:10.1016/ j.biopha.2020.109982

Jisha, N., Vysakh, A., Vijeesh, V., Anand, P. S., and Latha, M. S. (2020). Methanolic Extract of Muntingia Calabura L. Mitigates 1,2-Dimethyl Hydrazine Induced Colon Carcinogenesis in Wistar Rats. Nutr. Cancer, 1-13. doi:10.1080/ 01635581.2020 .1823438

Juan, T. K., Liu, K. C., Kuo, C. L., Yang, M. D., Chu, Y. L., Yang, J. L., et al. (2018). Tetrandrine Suppresses Adhesion, Migration and Invasion of Human colon Cancer SW620 Cells via Inhibition of Nuclear Factor-Kb, Matrix Metalloproteinase-2 and Matrix Metalloproteinase-9 Signaling Pathways. Oncol. Lett. 15, 7716-7724. doi:10.3892/ol.2018.8286

Kee, J.-Y., Han, Y.-H., Kim, D.-S., Mun, J.-G., Park, J., Jeong, M.-Y., et al. (2016). Inhibitory Effect of Quercetin on Colorectal Lung Metastasis through Inducing Apoptosis, and Suppression of Metastatic Ability. Phytomedicine 23, 1680-1690. doi:10.1016/j.phymed.2016.09.011

Kee, J.-Y., Han, Y.-H., Mun, J.-G., Um, J.-Y., and Hong, S.-H. (2018). Pharmacological Effect of Prohibited Combination Pair Panax Ginseng and Veratrum Nigrum on Colorectal Metastasis In Vitro and In Vivo. J. Ethnopharmacology 220, 177-187. doi:10.1016/j.jep.2018.03.036

Kim, H., Yu, Y., Choi, S., Lee, H., Yu, J., Lee, J.-H., et al. (2019a). Evodiamine Eliminates Colon Cancer Stem Cells via Suppressing Notch and Wnt Signaling. Molecules 24, 4520. doi:10.3390/molecules24244520

Kim, J., Kim, H.-Y., Hong, S., Shin, S., Kim, Y. A., Kim, N. S., et al. (2019b). A New Herbal Formula BP10A Exerted an Antitumor Effect and Enhanced Anticancer Effect of Irinotecan and Oxaliplatin in the colon Cancer PDTX Model. Biomed. Pharmacother. 116, 108987 doi:10.1016/ j.biopha.2019.108987

Kim, S.-Y., Yi, H.-K., Yun, B.-S., Lee, D.-Y., Hwang, P. H., Park, H.-R., et al. (2020). The Extract of the Immature Fruit of Poncirus Trifoliata Induces Apoptosis in Colorectal Cancer Cells via Mitochondrial Autophagy. Food Sci. Hum. Wellness 9, 237-244. doi:10.1016/j.fshw.2020.05.001

Kong, M.-y., Li, L.-y., Lou, Y.-m., Chi, H.-y., and Wu, J.-j. (2020). Chinese Herbal Medicines for Prevention and Treatment of Colorectal Cancer: From Molecular Mechanisms to Potential Clinical Applications. J. Integr. Med. 18, 369-384. doi:10.1016/j.joim.2020.07.005

Kwon, S., and Chan, A. T. (2020). Extracting the Benefits of Berberine for Colorectal Cancer. Lancet Gastroenterol. Hepatol. 5, 231-233. doi:10.1016/ s2468-1253(19)30430-3

Kyrgiou, M., Kalliala, I., Markozannes, G., Gunter, M. J., Paraskevaidis, E., Gabra, H., et al. (2017). Adiposity and Cancer at Major Anatomical Sites: Umbrella Review of the Literature. BMJ 356, j477. doi:10.1136/bmj.j477

La Vecchia, S., and Sebastián, C. (2020). Metabolic Pathways Regulating Colorectal Cancer Initiation and Progression. Semin. Cel Develop. Biol. 98, 63-70. doi:10.1016/j.semcdb.2019.05.018

Lan, Y.-H., Chiang, J.-H., Huang, W.-W., Lu, C.-C., Chung, J.-G., Wu, T.-S., et al. (2012). Activations of Both Extrinsic and Intrinsic Pathways in HCT 116 Human Colorectal Cancer Cells Contribute to Apoptosis through P53Mediated ATM/Fas Signaling byEmilia sonchifoliaExtract, a Folklore
Medicinal Plant. Evidence-Based Complement. Altern. Med. 2012, 1-13. doi:10.1155/2012/178178

Lee, G.-Y., Lee, J.-S., Son, C.-G., and Lee, N.-H. (2020). Combating Drug Resistance in Colorectal Cancer Using Herbal Medicines. Chin. J. Integr. Med. doi:10.1007/ s11655-020-3425-8

Lee, S.-R., Jin, H., Kim, W.-T., Kim, W.-J., Kim, S. Z., Leem, S.-H., et al. (2018a). Tristetraprolin Activation by Resveratrol Inhibits the Proliferation and Metastasis of Colorectal Cancer Cells. Int. J. Oncol. 53, 1269-1278. doi:10.3892/ijo.2018.4453

Lee, Y.-H., Song, N.-Y., Suh, J., Kim, D.-H., Kim, W., Ann, J., et al. (2018b). Curcumin Suppresses Oncogenicity of Human colon Cancer Cells by Covalently Modifying the Cysteine 67 Residue of SIRT1. Cancer Lett. 431, 219-229. doi:10.1016/j.canlet.2018.05.036

Leigh, A. B., Cheung, H. P., Lin, L.-z., Ng, T. B., Lao, L., Zhang, Y., et al. (2017). Comprehensive and Holistic Analysis of HT-29 Colorectal Cancer Cells and Tumor-Bearing Nude Mouse Model: Interactions Among Fractions Derived from the Chinese Medicine Formula Tian Xian Liquid in Effects on Human Colorectal Carcinoma. Integr. Cancer Ther. 16, 339-350. doi:10.1177/ 1534735416651969

Li, R., Ma, X., Song, Y., Zhang, Y., Xiong, W., Li, L., et al. (2019a). Anti-colorectal Cancer Targets of Resveratrol and Biological Molecular Mechanism: Analyses of Network Pharmacology, Human and Experimental Data. J. Cel Biochem 120, 11265-11273. doi:10.1002/jcb.28404

Li, S., Wang, X., Wang, G., Shi, P., Lin, S., Xu, D., et al. (2020). Ethyl Acetate Extract of Selaginella Doederleinii Hieron Induces Cell Autophagic Death and Apoptosis in Colorectal Cancer via PI3K-Akt-mTOR and AMPKa-Signaling Pathways. Front. Pharmacol. 11, 565090. doi:10.3389/fphar.2020.565090

Li, S. Z., Ren, J. W., Fei, J., Zhang, X. D., and Du, R. L. (2019b). Cordycepin Induces Bax-dependent A-poptosis in C-olorectal C-ancer C-ells. Mol. Med. Rep. 19, 901-908. doi:10.3892/mmr.2018.9717

Liang, W., Cui, J., Zhang, K., Xi, H., Cai, A., Li, J., et al. (2017). Shikonin Induces ROS-Based Mitochondria-Mediated Apoptosis in colon Cancer. Oncotarget 8, 109094-109106. doi:10.18632/oncotarget.22618

Lin, F.-x., Tian, L.-f., Lei, C.-y., Ding, C.-c., Shi, L., and Zhang, S.-f. (2017). Chinese Medicine for Outcomes in Colorectal Cancer Patients: A Retrospective Clinical Study. Chin. J. Integr. Med. 23, 648-653. doi:10.1007/s11655-016-2581-3

Lin, R., Piao, M., Song, Y., and Liu, C. (2020). Quercetin Suppresses AOM/DSSInduced Colon Carcinogenesis through its Anti-inflammation Effects in Mice. J. Immunol. Res. 2020, 1-10. doi:10.1155/2020/9242601

Lin, X., Xu, W., Shao, M., Fan, Q., Wen, G., Li, C., et al. (2015). Shenling Baizhu San Supresses Colitis Associated Colorectal Cancer through Inhibition of EpithelialMesenchymal Transition and Myeloid-Derived Suppressor Infiltration. BMC Complement. Altern. Med. 15, 126. doi:10.1186/s12906-015-0649-9

Lin, X., Yi, Z., Diao, J., Shao, M., Zhao, L., Cai, H., et al. (2014). ShaoYao Decoction Ameliorates Colitis-Associated Colorectal Cancer by Downregulating Proinflammatory Cytokines and Promoting Epithelial-Mesenchymal Transition. J. Translational Med. 12, 105. doi:10.1186/1479-5876-12-105

Liu, H., Huang, C., Wu, L., and Wen, B. (2016). Effect of Evodiamine and Berberine on miR-429 as an Oncogene in Human Colorectal Cancer. Onco Targets Ther. 9, 4121-4127. doi:10.2147/OTT.S104729

Liu, H., Liu, H., Zhou, Z., Parise, R. A., Chu, E., and Schmitz, J. C. (2018). Herbal Formula Huang Qin Ge Gen Tang Enhances 5-fluorouracil Antitumor Activity through Modulation of the E2F1/TS Pathway. Cell Commun Signal 16, 7. doi:10.1186/s12964-018-0218-1

Liu, J., Guo, Y., and Cao, J. (2020a). Matrine Triggers colon Cancer Cell Apoptosis and G0/G1 Cell Cycle Arrest via Mediation of microRNA-22. Phytotherapy Res. 34, 1619-1628. doi:10.1002/ptr.6626

Liu, L. H., Shi, R. J., and Chen, Z. C. (2020b). Paeonol Exerts Anti-tumor A-ctivity against C-olorectal C-ancer C-ells by I-nducing G0/G1 P-hase A-rrest and C-ell A-poptosis via I-nhibiting the $\mathrm{Wnt} / \beta$-catenin S-ignaling $\mathrm{P}$-athway. Int. J. Mol. Med. 46, 675-684. doi:10.3892/ijmm.2020.4629

Liu, R. H., Runyon, R. S., Wang, Y. C., Oliver, S. G., Fan, T. P., and Zhang, W. D. (2015). Deciphering Ancient Combinatorial Formulas: The Shexiang Baoxin Pill. Science ((6219 Suppl), 347, S40-S42. Available at: https://www.sciencemag. org/sites/default/files/custom-publishing/documents/TCM_Jan_16_2015_high \%20res.pdf.

Liu, T., Zhang, J., Chai, Z., Wang, G., Cui, N., and Zhou, B. (2017a). Ginkgo Biloba Extract EGb 761-induced Upregulation of LincRNA-P21 Inhibits Colorectal 
Cancer Metastasis by Associating with EZH2. Oncotarget 8, 91614-91627. doi:10.18632/oncotarget.21345

Liu, X., Ji, Q., Deng, W., Chai, N., Feng, Y., Zhou, L., et al. (2017b). JianPi JieDu Recipe Inhibits Epithelial-To-Mesenchymal Transition in Colorectal Cancer through TGF- $\beta /$ Smad Mediated Snail/E-Cadherin Expression. Biomed. Res. Int. 2017, 1-11. doi:10.1155/2017/2613198

Liu, Y., Yang, S., Wang, K., Lu, J., Bao, X., Wang, R., et al. (2020c). Cellular Senescence and Cancer: Focusing on Traditional Chinese Medicine and Natural Products. Cell Prolif. 53, e12894. doi:10.1111/cpr.12894

Liu, Y., Zhou, W., Mao, Z., and Chen, Z. (2019a). Analysis of Evodiae Fructus by Capillary Electrochromatography-Mass Spectrometry with MethylVinylimidazole Functionalized Organic Polymer Monolilth as Stationary Phases. J. Chromatogr. A 1602, 474-480. doi:10.1016/j.chroma.2019.06.011

Liu, Z., Wu, X., Lv, J., Sun, H., and Zhou, F. (2019b). Resveratrol Induces P53 in Colorectal Cancer through SET7/9. Oncol. Lett. 17, 3783-3789. doi:10.3892/ ol.2019.10034

Lu, L., Zhan, S., Liu, X., Zhao, X., Lin, X., and Xu, H. (2020a). Antitumor Effects and the Compatibility Mechanisms of Herb Pair Scleromitrion Diffusum (Willd.) R. J. Wang-Sculellaria Barbata D. Don. Front. Pharmacol. 11, 292. doi:10.3389/ fphar.2020.00292

Lu, Y., Zhang, R., Zhang, X., Zhang, B., and Yao, Q. (2020b). Curcumin May Reverse 5-fluorouracil Resistance on Colonic Cancer Cells by Regulating TET1NKD-Wnt Signal Pathway to Inhibit the EMT Progress. Biomed. Pharmacother. 129, 110381. doi:10.1016/j.biopha.2020.110381

Luan, X., Zhang, L.-J., Li, X.-Q., Rahman, K., Zhang, H., Chen, H.-Z., et al. (2020). Compound-based Chinese Medicine Formula: From Discovery to Compatibility Mechanism. J. Ethnopharmacology 254, 112687. doi:10.1016/ j.jep.2020.112687

Luo, H., Vong, C. T., Chen, H., Gao, Y., Lyu, P., Qiu, L., et al. (2019). Naturally Occurring Anti-cancer Compounds: Shining from Chinese Herbal Medicine. Chin. Med. 14, 48. doi:10.1186/s13020-019-0270-9

Lv, J., Jia, Y., Li, J., Kuai, W., Li, Y., Guo, F., et al. (2019). Gegen Qinlian Decoction Enhances the Effect of PD-1 Blockade in Colorectal Cancer with Microsatellite Stability by Remodelling the Gut Microbiota and the Tumour Microenvironment. Cell Death Dis 10, 415. doi:10.1038/s41419-019-1638-6

Marjaneh, R. M., Khazaei, M., Ferns, G. A., Avan, A., and Aghaee-Bakhtiari, S. H. (2018a). The Role of microRNAs in 5-FU Resistance of Colorectal Cancer: Possible Mechanisms. J. Cel Physiol 234, 2306-2316. doi:10.1002/jcp.27221

Marjaneh, R. M., Rahmani, F., Hassanian, S. M., Rezaei, N., Hashemzehi, M., Bahrami, A., et al. (2018b). Phytosomal Curcumin Inhibits Tumor Growth in Colitis-Associated Colorectal Cancer. J. Cel Physiol 233, 6785-6798. doi:10.1002/jcp. 26538

Mortezaee, K., Salehi, E., Mirtavoos-mahyari, H., Motevaseli, E., Najafi, M., Farhood, B., et al. (2019). Mechanisms of Apoptosis Modulation by Curcumin: Implications for Cancer Therapy. J. Cel Physiol 234, 12537-12550. doi:10.1002/jcp.28122

Mun, J. G., Kee, J. Y., Han, Y. H., Lee, S., Park, S. H., Jeon, H., et al. (2019). Galla Rhois Water Extract Inhibits Lung Metastasis by Inducing AMPK mediated Apoptosis and Suppressing Metastatic Properties of Colorectal Cancer Cells. Oncol. Rep. 41, 202-212. doi:10.3892/or.2018.6812

Narayan, P., Wahby, S., Gao, J. J., Amiri-Kordestani, L., Ibrahim, A., Bloomquist, E., et al. (2020). FDA Approval Summary: Atezolizumab Plus Paclitaxel Protein-Bound for the Treatment of Patients with Advanced or Metastatic TNBC Whose Tumors Express PD-L1. Clin. Cancer Res. 26, 2284-2289. doi:10.1158/1078-0432.CCR-19-3545

Nazeri, M., Mirzaie-Asl, A., Saidijam, M., and Moradi, M. (2020). Methanolic Extract of Artemisia Absinthium Prompts Apoptosis, Enhancing Expression of Bax/Bcl-2 Ratio, Cell Cycle Arrest, Caspase-3 Activation and Mitochondrial Membrane Potential Destruction in Human Colorectal Cancer HCT-116 Cells. Mol. Biol. Rep. 47, 8831-8840. doi:10.1007/s11033-020-05933-2

Oh, N. S., Lee, J. Y., Kim, Y.-T., Kim, S. H., and Lee, J.-H. (2020). Cancer-protective Effect of a Synbiotic Combination between Lactobacillus Gasseri 505 and a Cudrania Tricuspidata Leaf Extract on Colitis-Associated Colorectal Cancer. Gut Microbes 12, 1785803. doi:10.1080/19490976.2020.1785803

Palmieri, A., Scapoli, L., Iapichino, A., Mercolini, L., Mandrone, M., Poli, F., et al. (2019). Berberine and Tinospora Cordifolia Exert a Potential Anticancer Effect on colon Cancer Cells by Acting on Specific Pathways. Int. J. Immunopathol Pharmacol. 33, 205873841985556. doi:10.1177/2058738419855567
Pan, J., Xu, Y., Song, H., Zhou, X., Yao, Z., and Ji, G. (2017). Extracts of Zuo Jin Wan, a Traditional Chinese Medicine, Phenocopies 5-HTR1D Antagonist in Attenuating Wnt $/ \beta$-Catenin Signaling in Colorectal Cancer Cells. BMC Complement. Altern. Med. 17, 506. doi:10.1186/s12906-017-2006-7

Pang, B., Xu, X., Lu, Y., Jin, H., Yang, R., Jiang, C., et al. (2019). Prediction of New Targets and Mechanisms for Quercetin in the Treatment of Pancreatic Cancer, colon Cancer, and Rectal Cancer. Food Funct. 10, 5339-5349. doi:10.1039/ c9fo01168d

Patel, S. S., Acharya, A., Ray, R. S., Agrawal, R., Raghuwanshi, R., and Jain, P. (2020). Cellular and Molecular Mechanisms of Curcumin in Prevention and Treatment of Disease. Crit. Rev. Food Sci. Nutr. 60, 887-939. doi:10.1080/ 10408398.2018.1552244

Peng, W., Zhang, S., Zhang, Z., Xu, P., Mao, D., Huang, S., et al. (2018). Jianpi Jiedu Decoction, a Traditional Chinese Medicine Formula, Inhibits Tumorigenesis, Metastasis, and Angiogenesis through the mTOR/HIF-1a/VEGF Pathway. J. Ethnopharmacology 224, 140-148. doi:10.1016/j.jep.2018.05.039

Pengpid, S., and Peltzer, K. (2018). Utilization of Traditional and Complementary Medicine in Indonesia: Results of a National Survey in 2014-15. Complement. Therapies Clin. Pract. 33, 156-163. doi:10.1016/j.ctcp.2018.10.006

Qi, F., Wei, L., Shen, A., Chen, Y., Lin, J., Chu, J., et al. (2016). Pien Tze Huang Inhibits the Proliferation, and Induces the Apoptosis and Differentiation of Colorectal Cancer Stem Cells via Suppression of the Notch1 Pathway. Oncol. Rep. 35, 511-517. doi:10.3892/or.2015.4378

Qi, J., Yu, J., Li, Y., Luo, J., Zhang, C., Ou, S., et al. (2019). Alternating Consumption of $\beta$-glucan and Quercetin Reduces Mortality in Mice with Colorectal Cancer. Food Sci. Nutr. 7, 3273-3285. doi:10.1002/fsn3.1187

Qiao, L., Han, M., Gao, S., Shao, X., Wang, X., Sun, L., et al. (2020). Research Progress on Nanotechnology for Delivery of Active Ingredients from Traditional Chinese Medicines. J. Mater. Chem. B 8, 6333-6351. doi:10.1039/d0tb01260b

Qiu, J. (2007). China Plans to Modernize Traditional Medicine. Nature 446, 590-591. doi:10.1038/446590a

Qu, Y., Chu, B., Wei, X., Lei, M., Hu, D., Zha, R., et al. (2019). Redox/pH DualStimuli Responsive Camptothecin Prodrug Nanogels for "On-Demand" Drug Delivery. J. Controlled Release 296, 93-106. doi:10.1016/j.jconrel.2019.01.016

Rafiee, Z., Nejatian, M., Daeihamed, M., and Jafari, S. M. (2019). Application of Different Nanocarriers for Encapsulation of Curcumin. Crit. Rev. Food Sci. Nutr. 59, 3468-3497. doi:10.1080/10408398.2018.1495174

Rauf, A., Imran, M., Butt, M. S., Nadeem, M., Peters, D. G., and Mubarak, M. S. (2018). Resveratrol as an Anti-cancer Agent: A Review. Crit. Rev. Food Sci. Nutr. 58, 1428-1447. doi:10.1080/10408398.2016.1263597

Restivo, I., Tesoriere, L., Frazzitta, A., Livrea, M. A., Attanzio, A., and Allegra, M. (2020). Anti-Proliferative Activity of A Hydrophilic Extract of Manna from Fraxinus Angustifolia Vahl through Mitochondrial Pathway-Mediated Apoptosis and Cell Cycle Arrest in Human Colon Cancer Cells. Molecules 25, 5055. doi:10.3390/molecules25215055

Ruan, H., Zhan, Y. Y., Hou, J., Xu, B., Chen, B., Tian, Y., et al. (2017). Berberine Binds RXRa to Suppress $\beta$-catenin Signaling in colon Cancer Cells. Oncogene 36, 6906-6918. doi:10.1038/onc.2017.296

Rytsyk, O., Soroka, Y., Shepet, I., Vivchar, Z., Andriichuk, I., Lykhatskyi, P., et al. (2020). Experimental Evaluation of the Effectiveness of Resveratrol as an Antioxidant in Colon Cancer Prevention. Nat. Product. Commun. 15, 1934578X2093274. doi:10.1177/1934578x20932742

San Hipólito-Luengo, Á., Alcaide, A., Ramos-González, M., Cercas, E., Vallejo, S., Romero, A., et al. (2017). Dual Effects of Resveratrol on Cell Death and Proliferation of Colon Cancer Cells. Nutr. Cancer 69, 1019-1027. doi:10.1080/01635581.2017.1359309

Sałaga, M., Zatorski, H., Sobczak, M., Chen, C., and Fichna, J. (2014). Chinese Herbal Medicines in the Treatment of IBD and Colorectal Cancer: a Review. Curr. Treat. Options. Oncol. 15, 405-420. doi:10.1007/s11864-014-0288-2

Sevastre, B., Sarpataki, O., Stan, R., Taulescu, M., Sevastre-Berghian, A., Olah, N., et al. (2017). Anticancer Activity of Euonymus Europaeus Fruits Extract on Human Melanoma Cells. Farmacia 65, 56-62. Available at: https:// farmaciajournal.com/issue-articles/anticancer-activity-of-euonymus-europaeusfruits-extract-on-human-melanoma-cells/

Shaheer, K., Somashekarappa, H., and Lakshmanan, M. D. (2020). Piperine Sensitizes Radiation-resistant Cancer Cells towards Radiation and Promotes 
Intrinsic Pathway of Apoptosis. J. Food Sci. 85, 4070-4079. doi:10.1111/17503841.15496

Shen, A., Chen, H., Chen, Y., Lin, J., Lin, W., Liu, L., et al. (2014). Pien Tze Huang Overcomes Multidrug Resistance and Epithelial-Mesenchymal Transition in Human Colorectal Carcinoma Cells via Suppression of TGF- $\beta$ Pathway. Evidence-Based Complement. Altern. Med. 2014, 1-10. doi:10.1155/2014/ 679436

Shen, C.-Y., Jiang, J.-G., Yang, L., Wang, D.-W., and Zhu, W. (2017). Anti-ageing Active Ingredients from Herbs and Nutraceuticals Used in Traditional Chinese Medicine: Pharmacological Mechanisms and Implications for Drug Discovery. Br. J. Pharmacol. 174, 1395-1425. doi:10.1111/bph.13631

Shen, Z.-q., Wang, J., Tan, W.-f., and Huang, T.-m. (2020). Berberine Inhibits Colorectal Tumor Growth by Suppressing SHH Secretion. Acta Pharmacol. Sin. doi:10.1038/s41401-020-00514-2

Shi, X., Zhu, M., Gong, Z., Yang, T., Yu, R., Wang, J., et al. (2020). Homoharringtonine Suppresses LoVo Cell Growth by Inhibiting EphB4 and the PI3K/AKT and MAPK/EKR1/2 Signaling Pathways. Food Chem. Toxicol. 136, 110960. doi:10.1016/j.fct.2019.110960

Shitara, K., Zhang, Y., Fujitani, K., Koeda, K., Hara, H., Nakayama, N., et al. (2017). Nab-paclitaxel versus Solvent-Based Paclitaxel in Patients with Previously Treated Advanced Gastric Cancer (ABSOLUTE): an Open-Label, Randomised, Non-inferiority, Phase 3 Trial. Food Chem. Toxicol. 2, 277-287. doi:10.1016/s2468-1253(16)30219-9

Siegel, R. L., Miller, K. D., Goding Sauer, A., Fedewa, S. A., Butterly, L. F., Anderson, J. C., et al. (2020). Colorectal Cancer Statistics, 2020. CA A. Cancer J. Clin. 70, 145-164. doi:10.3322/caac.21601

Singh, A. P., Singh, R., Verma, S. S., Rai, V., Kaschula, C. H., Maiti, P., et al. (2019). Health Benefits of Resveratrol: Evidence from Clinical Studies. Med. Res. Rev. 39, 1851-1891. doi:10.1002/med.21565

Song, M., Chan, A. T., and Sun, J. (2020). Influence of the Gut Microbiome, Diet, and Environment on Risk of Colorectal Cancer. Gastroenterology 158, 322-340. doi:10.1053/j.gastro.2019.06.048

Sritharan, S., and Sivalingam, N. (2021). Curcumin Induced Apoptosis Is Mediated through Oxidative Stress in Mutated P53 and Wild Type P53 colon Adenocarcinoma Cell Lines. J. Biochem. Mol. Toxicol. 35, e22616. doi:10.1002/jbt.22616

Su, T., Bai, J.-X., Chen, Y.-J., Wang, X.-N., Fu, X.-Q., Li, T., et al. (2017). An Ethanolic Extract of Ampelopsis Radix Exerts Anti-colorectal Cancer Effects and Potently Inhibits STAT3 Signaling In Vitro. Front. Pharmacol. 8, 227. doi:10.3389/fphar.2017.00227

Sui, H., Duan, P., Guo, P., Hao, L., Liu, X., Zhang, J., et al. (2017). Zhi Zhen Fang Formula Reverses Hedgehog Pathway Mediated Multidrug Resistance in Colorectal Cancer. Oncol. Rep. 38, 2087-2095. doi:10.3892/or.2017.5917

Sui, H., Zhang, L., Gu, K., Chai, N., Ji, Q., Zhou, L., et al. (2020). YYFZBJS Ameliorates Colorectal Cancer Progression in ApcMin/+ Mice by Remodeling Gut Microbiota and Inhibiting Regulatory T-Cell Generation. Cel Commun Signal 18, 113. doi:10.1186/s12964-020-00596-9

Sui, H., Zhou, L. H., Zhang, Y. L., Huang, J. P., Liu, X., Ji, Q., et al. (2016). Evodiamine Suppresses ABCG2 Mediated Drug Resistance by Inhibiting P50/ p65 NF-kB Pathway in Colorectal Cancer. J. Cel. Biochem. 117, 1471-1481. doi:10.1002/jcb.25451

Sun, G., Wei, L., Feng, J., Lin, J., and Peng, J. (2016). Inhibitory Effects of Hedyotis Diffusa Willd. On Colorectal Cancer Stem Cells. Oncol. Lett. 11, 3875-3881. doi:10.3892/ol.2016.4431

Sun, J., Xu, K., Qiu, Y., Gao, H., Xu, J., Tang, Q., et al. (2017). Bufalin Reverses Acquired Drug Resistance by Inhibiting Stemness in Colorectal Cancer Cells. Oncol. Rep. 38, 1420-1430. doi:10.3892/or.2017.5826

Sun, Q., Xie, L., Song, J., and Li, X. (2020b). Evodiamine: A Review of its Pharmacology, Toxicity, Pharmacokinetics and Preparation Researches. J. Ethnopharmacology 262, 113164. doi:10.1016/j.jep.2020.113164

Sun, Q., Yin, P., Zhang, M., Zeng, S., Chen, L., Zhou, L. J., et al. (2020a). Ursolic Acid: A Systematic Review of its Pharmacology, Toxicity and Rethink on its Pharmacokinetics Based on PK-PD Model. Fitoterapia 147, 104735. doi:10.1016/j.fitote.2020.104735

Sung, H., Ferlay, J., Siegel, R. L., Laversanne, M., Soerjomataram, I., Jemal, A., et al. (2021). Global Cancer Statistics 2020: GLOBOCAN Estimates of Incidence and Mortality Worldwide for 36 Cancers in 185 Countries. CA A. Cancer J. Clin. 71, 209-249. doi:10.3322/caac.21660
Tai, C. J., Wang, C. K., Tai, C. J., Lin, Y. F., Lin, C. S., Jian, J. Y., et al. (2013). Aqueous Extract of Solanum nigrum Leaves Induces Autophagy and Enhances Cytotoxicity of Cisplatin, Doxorubicin, Docetaxel, and 5-Fluorouracil in Human Colorectal Carcinoma Cells. Evid. Based Complement. Alternat Med. 2013, 514719. doi:10.1155/2013/514719

Tan, L., Lei, N., He, M., Zhang, M., Sun, Q., Zeng, S., et al. (2020). Scutellarin Protects against Human Colorectal Cancer In Vitro by Down Regulation of Hedgehog Signaling Pathway Activity. Int. J. Pharmacol. 16, 53-62. doi:10.3923/ijp.2020.53.62

Tang, Q., Liu, L., Zhang, H., Xiao, J., and Hann, S. S. (2020). Regulations of miR183-5p and Snail-Mediated Shikonin-Reduced Epithelial-Mesenchymal Transition in Cervical Cancer Cells. Drug. Des. Devil. Ther. Vol. 14, 577-589. doi:10.2147/DDDT.S236216

Tao, L., Yang, J. K., Gu, Y., Zhou, X., Zhao, A. G., Zheng, J., et al. (2015). Weichang'an and 5-fluorouracil Suppresses Colorectal Cancer in a Mouse Model. World. J. Gastroentrol. 21, 1125-1139. doi:10.3748/wjg.v21.i4.1125

Tian, B., and Liu, J. (2020). Resveratrol: a Review of Plant Sources, Synthesis, Stability, Modification and Food Application. J. Sci. Food Agric. 100, 1392-1404. doi:10.1002/jsfa.10152

Tomeh, M., Hadianamrei, R., and Zhao, X. (2019). A Review of Curcumin and its Derivatives as Anticancer Agents. Int. J. Mol. Sci. 20, 1033. doi:10.3390/ ijms 20051033

Tsai, D. H., Chung, C. H., and Lee, K. T. (2018). Antrodia Cinnamomea Induces Autophagic Cell Death via the CHOP/TRB3/Akt/mTOR Pathway in Colorectal Cancer Cells. Sci. Rep. 8, 17424. doi:10.1038/s41598-018-35780-y

Untch, , M., Jackisch, C., Schneeweiss, A., Schmatloch, S., Aktas, B., Denkert, C., et al. (2020). NAB-paclitaxel Improves Disease-free Survival in Early Breast Cancer:GBG 69-GeparSepto. J. Clin. Oncol. 37, 2226. doi:10.1200/jco.18.01842

Verdura, S., Cuyàs, E., Cortada, E., Brunet, J., Lopez-Bonet, E., Martin-Castillo, B., et al. (2020). Resveratrol Targets PD-L1 Glycosylation and Dimerization to Enhance Antitumor T-Cell Immunity. Aging 12, 8-34. doi:10.18632/ aging.102646

Vivarelli, S., Salemi, R., Candido, S., Falzone, L., Santagati, M., Stefani, S., et al. (2019). Gut Microbiota and Cancer: From Pathogenesis to Therapy. Cancers 11, 38. doi:10.3390/cancers 11010038

Vodenkova, S., Buchler, T., Cervena, K., Veskrnova, V., Vodicka, P., and Vymetalkova, V. (2020). 5-fluorouracil and Other Fluoropyrimidines in Colorectal Cancer: Past, Present and Future. Pharmacol. Ther. 206, 107447. doi:10.1016/j.pharmthera.2019.107447

Wan, G., Xie, M., Zhang, X., and Li, M. (2019). Chang-wei-qing, a Chinese Herbal Formula, Ameliorates Colitis-Associated Tumour Development via Inhibiting NF-Kb and STAT3 Signalling Pathway. Pharm. Biol. 57, 231-237. doi:10.1080/ 13880209.2019.1577465

Wan, S., Tan, L., Lei, N., Shi, Y. R., He, M., Zhang, M., et al. (2018). Compound Bieshe Kang'ai Inhibits Proliferation and Induces Apoptosis in HCT116 Human Colorectal Cancer Cells. Trop. J. Pharm. Res. 17, 2163-2168. doi:10.4314/tjpr.v17i11.8

Wang, R., Liu, H., Shao, Y., Wang, K., Yin, S., Qiu, Y., et al. (2019). Sophoridine Inhibits Human Colorectal Cancer Progression via Targeting MAPKAPK2. Mol. Cancer Res. 17, 2469-2479. doi:10.1158/1541-7786.mcr-19-0553

Wang, X., Liu, C., Wang, J., Fan, Y., Wang, Z., and Wang, Y. (2017). Oxymatrine Inhibits the Migration of Human Colorectal Carcinoma RKO Cells via Inhibition of PAI-1 and the TGF- $1 /$ Smad Signaling Pathway. Oncol. Rep. 37, 747-753. doi:10.3892/or.2016.5292

Wang, Y., Liu, P., Fang, Y., Tian, J., Li, S., Xu, J., et al. (2020). The Effect of LongTerm Traditional Chinese Medicine Treatment on Survival Time of Colorectal Cancer Based on Propensity Score Matching: A Retrospective Cohort Study. Evidence-Based Complement. Altern. Med. 2020, 1-12. doi:10.1155/2020/ 7023420

Wang, Z., Qi, F., Cui, Y., Zhao, L., Sun, X., Tang, W., et al. (2018). An Update on Chinese Herbal Medicines as Adjuvant Treatment of Anticancer Therapeutics. Biosci. Trends. 12, 220-239. doi:10.5582/bst.2018.01144

Wei, L., Chen, P., Chen, Y., Shen, A., Chen, H., Lin, W., et al. (2014). Pien Tze Huang Suppresses the Stem-like Side Population in Colorectal Cancer Cells. Mol. Med. Rep. 9, 261-266. doi:10.3892/mmr.2013.1760

Wong, S. K., Chin, K.-Y., and Ima-Nirwana, S. (2020). Quercetin as an Agent for Protecting the Bone: A Review of the Current Evidence. Int. J. Mol. Sci. 21, 6448. doi:10.3390/ijms21176448 
Wu, R., Wang, L., Yin, R., Hudlikar, R., Li, S., Kuo, H. C. D., et al. (2020). Epigenetics/epigenomics and Prevention by Curcumin of Early Stages of Inflammatory-driven colon Cancer. Mol. Carcinog 59, 227-236. doi:10.1002/ mc.23146

Wu, S., Qiu, Y., Shao, Y., Yin, S., Wang, R., Pang, X., et al. (2018). Lycorine Displays Potent Antitumor Efficacy in Colon Carcinoma by Targeting STAT3. Front. Pharmacol. 9, 881. doi:10.3389/fphar.2018.00881

Xi, S.-y., Teng, Y.-h., Chen, Y., Li, J.-p., Zhang, Y.-y., Liu, S.-l., et al. (2015). Jianpi Huayu Decoction Inhibits Proliferation in Human Colorectal Cancer Cells (SW480) by Inducing G0/G1-phase Cell Cycle Arrest and Apoptosis. EvidenceBased Complement. Altern. Med. 2015, 1-8. doi:10.1155/2015/236506

Xiang, L., He, B., Liu, Q., Hu, D., Liao, W., Li, R., et al. (2020). Antitumor Effects of Curcumin on the Proliferation, Migration and Apoptosis of Human Colorectal Carcinoma HCT-116 C-ells. Oncol. Rep. 44, 1997-2008. doi:10.3892/ or.2020.7765

Xiang, Y., Guo, Z., Zhu, P., Chen, J., and Huang, Y. (2019). Traditional Chinese Medicine as a Cancer Treatment: Modern Perspectives of Ancient but Advanced Science. Cancer Med. 8, 1958-1975. doi:10.1002/cam4.2108

Xu, T., Wang, Q., and Liu, M. (2020). A Network Pharmacology Approach to Explore the Potential Mechanisms of Huangqin-Baishao Herb Pair in Treatment of Cancer. Med. Sci. Monit. 26, e923199. doi:10.12659/MSM.923199

Xue, J., Jin, X., Wan, X., Yin, X., Fang, M., Liu, T., et al. (2019). Effects and Mechanism of Tanshinone II A in Proliferation, Apoptosis, and Migration of Human Colon Cancer Cells. Med. Sci. Monit. 25, 4793-4800. doi:10.12659/ MSM.914446

Yan, Z., Feng, J., Peng, J., Lai, Z., Zhang, L., Jin, Y., et al. (2017a). Chloroform Extract of Hedyotis Diffusa Willd Inhibits Viability of Human Colorectal Cancer Cells via Suppression of AKT and ERK Signaling Pathways. Oncol. Lett. 14, 7923-7930. doi:10.3892/ol.2017.7245

Yan, Z., Lai, Z., and Lin, J. (2017b). Anticancer Properties of Traditional Chinese Medicine. Comb. Chem. High. Thoughput. Screen. 20, 423-429. doi:10.2174/ 1386207320666170116141818

Yang, B., Bai, H., Sa, Y., Zhu, P., and Liu, P. (2020). Inhibiting EMT, Stemness and Cell Cycle Involved in Baicalin-Induced Growth Inhibition and Apoptosis in Colorectal Cancer Cells. J. Cancer 11, 2303-2317. doi:10.7150/jca.37242

Yang, H., Liu, J.-X., Shang, H.-X., Lin, S., Zhao, J.-Y., and Lin, J.-M. (2019a). Qingjie Fuzheng Granules Inhibit Colorectal Cancer Cell Growth by the PI3K/AKT and ERK Pathways. World. J. Gastrointest.Oncol. 11, 377-392. doi:10.4251/ wjgo.v11.i5.377

Yang, L., Liu, Y., Wang, M., Qian, Y., Dong, X., Gu, H., et al. (2016). Quercetininduced Apoptosis of HT-29 colon Cancer Cells via Inhibition of the AktCSN6-Myc Signaling axis. Mol. Med. Rep. 14, 4559-4566. doi:10.3892/ mmr.2016.5818

Yang, N., Zhao, Y., Wang, Z., Liu, Y., and Zhang, Y. (2017). Scutellarin Suppresses Growth and Causes Apoptosis of Human Colorectal Cancer Cells by Regulating the P53 Pathway. Mol. Med. Rep. 15, 929-935. doi: $10.3892 / \mathrm{mmr} .2016 .6081$

Yang, Y., Wang, T., Chen, D., Ma, Q., Zheng, Y., Liao, S., et al. (2019b). Quercetin Preferentially Induces Apoptosis in KRAS-Mutant Colorectal Cancer Cells via JNK Signaling Pathways. Cell Biol Int 43, 117-124. doi:10.1002/cbin.11055

Yao, Y., Rao, C., Zheng, G., and Wang, S. (2019). Luteolin Suppresses Colorectal Cancer Cell Metastasis via Regulation of the miR-384/pleiotrophin axis. Oncol. Rep. 42, 131-141. doi:10.3892/or.2019.7136

Ye, L., Jia, Y., Ji, K., Sanders, A. J., Xue, K., Ji, J., et al. (2015). Traditional Chinese Medicine in the Prevention and Treatment of Cancer and Cancer Metastasis. Oncol. Lett. 10, 1240-1250. doi:10.3892/ol.2015.3459

You, Q., Li, L., Li, D., Yang, D., Chen, L., Chen, H.-p., et al. (2020). Meta-Analysis on the Chinese Herbal Formula Xiaoer-Feike Granules as a Complementary Therapy for Children with Acute Lower Respiratory Infections. Front. Pharmacol. 11, 496348. doi:10.3389/fphar.2020.496348

Yu, Y.-N., Yu, T.-C., Zhao, H.-J., Sun, T.-T., Chen, H.-M., Chen, H.-Y., et al. (2015). Berberine May rescue Fusobacterium Nucleatum-Induced Colorectal Tumorigenesis by Modulating the Tumor Microenvironment. Oncotarget 6, 32013-32026. doi:10.18632/oncotarget.5166

Yuan, M., Meng, W., Liao, W., and Lian, S. (2018). Andrographolide Antagonizes TNF- $\alpha$-Induced IL-8 via Inhibition of NADPH Oxidase/ROS/NF-kB and Src/
MAPKs/AP-1 Axis in Human Colorectal Cancer HCT116 Cells. J. Agric. Food Chem. 66, 5139-5148. doi:10.1021/acs.jafc.8b00810

Yue, G. G. L., Chan, Y. Y., Liu, W., Gao, S., Wong, C. W., Lee, J. K. M., et al. (2020). Effectiveness of Scutellaria Barbata Water Extract on Inhibiting colon Tumor Growth and Metastasis in Tumor-bearing Mice. Phytotherapy Res. 35, 361-373. doi: $10.1002 /$ ptr.6808

Zhang, J.-W., Li, L.-X., Wu, W.-Z., Pan, T.-J., Yang, Z.-S., and Yang, Y.-K. (2018). Anti-Tumor Effects of Paeoniflorin on Epithelial-To-Mesenchymal Transition in Human Colorectal Cancer Cells. Med. Sci. Monit. 24, 6405-6413. doi:10.12659/MSM.912227

Zhang, L.-L., Zhan, L., Jin, Y.-D., Min, Z.-L., Wei, C., Wang, Q., et al. (2017b). SIRT2 Mediated Antitumor Effects of Shikonin on Metastatic Colorectal Cancer. Eur. J. Pharmacol. 797, 1-8. doi:10.1016/ j.ejphar.2017.01.008

Zhang, L., Cai, Q. Y., Liu, J., Peng, J., Chen, Y. Q., Sferra, T., et al. (2019a). Ursolic Acid Suppresses the Invasive Potential of Colorectal Cancer Cells by Regulating the TGF- $\beta 1 / \mathrm{ZEB} 1 / \mathrm{miR}-200 \mathrm{c}$ S-ignaling P-athway. Oncol. Lett. 18, 3274-3282. doi:10.3892/ol.2019.10604

Zhang, L., Fang, Y., Feng, J.-Y., Cai, Q.-Y., Wei, L.-H., Lin, S., et al. (2017a). Chloroform Fraction of Scutellaria Barbata D. Don Inhibits the Growth of Colorectal Cancer Cells by Activating miR-34a. Oncol. Rep. 37, 3695-3701. doi:10.3892/or.2017.5625

Zhang, L., Naeem, A., Wei, S., Li, Z., Zang, Z., Wang, M., et al. (2019b). PPTS Inhibits the TGF-B1-Induced Epithelial-Mesenchymal Transition in Human Colorectal Cancer SW480 Cells. Evidence-Based Complement. Altern. Med. 2019, 1-10. doi:10.1155/2019/2683534

Zhang, N., Peng, F., Wang, Y., Yang, L., Wu, F., Wang, X., et al. (2020a). Shikonin Induces Colorectal Carcinoma Cells Apoptosis and Autophagy by Targeting Galectin-1/JNK Signaling axis. Int. J. Biol. Sci. 16, 147-161. doi:10.7150/ ijbs. 36955

Zhang, S. Q., Xu, H. B., Zhang, S. J., and Li, X. Y. (2020c). Identification of the Active Compounds and Significant Pathways of Artemisia Annua in the Treatment of Non-small Cell Lung Carcinoma Based on Network Pharmacology. Med. Sci. Monitor 26, e923624. doi:10.12659/msm.923624

Zhang, S., Yang, Y., Hua, Y., Hu, C., and Zhong, Y. (2020b). NCTD Elicits Proapoptotic and Antiglycolytic Effects on Colorectal Cancer Cells via Modulation of Fam46c Expression and Inhibition of ERK1/2 Signaling. Mol. Med. Rep. 22, 774-782. doi:10.3892/mmr.2020.11151

Zhang, Y., Liu, X., Yu, M., Xu, M., Xiao, Y., Ma, W., et al. (2020d). Berberine Inhibits Proliferation and Induces G0/G1 Phase Arrest in Colorectal Cancer Cells by Downregulating IGF2BP3. Life Sci. 260, 118413. doi:10.1016/ j.lfs.2020.118413

Zhang, Z., Chen, H., Xu, C., Song, L., Huang, L., Lai, Y., et al. (2016). Curcumin Inhibits Tumor Epithelial-Mesenchymal Transition by Downregulating the Wnt Signaling Pathway and Upregulating NKD2 Expression in colon Cancer cells. Oncol. Rep. 35, 2615-2623. doi:10.3892/or.2016.4669

Zhao, H., Chen, Y., Gu, D., Ren, L., Yao, S., and Chen, L. (2021). Colorectal Cancer, Gut Microbiota and Traditional Chinese Medicine: A Systematic Review. Am. J. Chin. Med. 49, 805-828. doi:10.1142/S0192415X21500385

Zhao, L.-C., Li, J., Liao, K., Luo, N., Shi, Q.-Q., Feng, Z.-Q., et al. (2015). Evodiamine Induces Apoptosis and Inhibits Migration of HCT-116 Human Colorectal Cancer Cells. Int. J. Mol. Sci. 16, 27411-27421. doi:10.3390/ ijms 161126031

Zheng, Z.-H., You, H.-Y., Feng, Y.-J., and Zhang, Z.-T. (2020). LncRNA KCNQ1OT1 Is a Key Factor in the Reversal Effect of Curcumin on Cisplatin Resistance in the Colorectal Cancer Cells. Mol. Cell Biochem. 476 (7), 2575-2585. doi:10.1007/s11010-020-03856-x

Zhou, J.-Y., Chen, M., Wu, C.-E., Zhuang, Y.-W., Chen, Y.-G., and Liu, S.-L. (2019a). The Modified Si-Jun-Zi Decoction Attenuates colon Cancer Liver Metastasis by Increasing Macrophage Cells. BMC Complement. Altern. Med. 19, 86. doi:10.1186/s12906-019-2498-4

Zhou, M., Hong, Y., Lin, X., Shen, L., and Feng, Y. (2017). Recent Pharmaceutical Evidence on the Compatibility Rationality of Traditional Chinese Medicine. J. Ethnopharmacology 206, 363-375. doi:10.1016/j.jep.2017.06.007

Zhou, P., Li, X.-P., Jiang, R., Chen, Y., Lv, X.-T., Guo, X.-X., et al. (2019b). Evodiamine Inhibits Migration and Invasion by Sirt1-Mediated post- 
translational Modulations in Colorectal Cancer. Anticancer Drugs 30, 611-617. doi:10.1097/CAD.0000000000000760

Zhou, Q., Chen, Y.-G., Xiao, J., Chen, T.-t., Liu, J.-r., Zhou, W., et al. (2019c). Traditional Chinese Medicine (Xiaoai Jiedu Decoction) as an Adjuvant Treatment for Prevention New Colorectal Adenomatous Polyp Occurrence in post-polypectomy. Medicine (Baltimore) 98, e16680. doi:10.1097/ MD.0000000000016680

Zong, S., Tang, Y., Li, W., Han, S., Shi, Q., Ruan, X., et al. (2020). A Chinese Herbal Formula Suppresses Colorectal Cancer Migration and Vasculogenic Mimicry through ROS/HIF-1a/MMP2 Pathway in Hypoxic Microenvironment. Front. Pharmacol. 11, 705. doi:10.3389/fphar.2020.00705
Conflict of Interest: The authors declare that the research was conducted in the absence of any commercial or financial relationships that could be construed as a potential conflict of interest.

Copyright (c) 2021 Sun, He, Zhang, Zeng, Chen, Zhao, Yang, Liu, Ren and Xu. This is an open-access article distributed under the terms of the Creative Commons Attribution License (CC BY). The use, distribution or reproduction in other forums is permitted, provided the original author(s) and the copyright owner(s) are credited and that the original publication in this journal is cited, in accordance with accepted academic practice. No use, distribution or reproduction is permitted which does not comply with these terms. 